\title{
KEADILAN JENDER DAN SANKSI ATAS ISTRI DALAM HUKUM FORMAL KELUARGA ISLAM
}

\author{
Oleh: Rina Septiani, MA.Hk ${ }^{1}$
}

\begin{abstract}
Abstrak
Penelitian ini ingin membuktikan bahwasanya peraturan terkait sanksi dipandang dari perspektif keadilan jender belum memberikan keadilan selain itu peraturan terkait sanksi masih mengakomodir ketentuan dalam fikih. Meskipun dalam prakteknya para hakim telah mengupayakan perlindungan bagi perempuan, tetapi selama peraturannya belum diubah, maka keadilan bagi perempuan tidak dapat ditegakkan.

Penelitian ini memfokuskan pada beberapa pertanyaan yaitu dalam hal isu keluarga apa saja wanita dalam keluarga Islam memperoleh sanksi serta bagaimana sanksi-sanksi tersebut dianalisis dengan perspektif keadilan jender. Penelitian ini menemukan bahwa dalam hukum Islam terdapat kesetaraan terlihat dari sanksi yang dijatuhkan kepada wanita dalam hal nushuz dan cerai gugat serta khuluk walaupun dalam kenyataannya khusunya di Pengadilan Agama masih ada beberapa putusan yang tidak mencerminkan nilai-nilai keadilan khususnya bagi wanita apabila kita melihatnya melalui kajian keadilan jender di Indonesia. Penelitian ini merupakan penelitian kualitatif yang bersifat deskriptif analisis berdasarkan kajian teks. Pendekatan yang digunakan dalam penelitian ini adalah normative legal research.
\end{abstract}

\begin{abstract}
The objective of this research is to prove that regulations on the imposition of sanctions from gender based justice perspective has yet to bring justice. In addition, regulations concerning sanction charge are still accommodating provisions set forth in figh laws. In practice, judges have toiled on women protection; however, as long as the regulations remain unchanged, justice for women can't be truly upheld. This issue has actually sparred discrepancies among scholars. This research focuses on the exploration of some issues, such as in what domestic issues women of Islamic family will be liable for sanctions and how such sanctions will be analyzed from gender based justice perspective. This research found out that there is equality in Islamic law. It can be seen from the sanctions charged to women in the case of nushuz, divorce, and khuluk even though, in reality, there are some decisions made by Religious Court, which do
\end{abstract}

1 Alumni Sps UIN Jakarta 
not reflect justice values especially for women if it is reviewed from gender perspective in Indonesia. This research is a qualitative study corroborated with descriptive analysis based on textual reviews. Methods adopted for this research is that of normative legal research.

Kata Kunci: Kekerasan, Nushuz, kesetaraan, keadilan, jender

\section{A. Jender dan Feminisme dalam Islam}

Jender sebagai ideologi menimbulkan keyakinan bahwa posisi perempuan dan laki-laki merupakan kodrat Tuhan, padahal yang dapat dikatakan kodrat Tuhan adalah perbedaaan biologis, yaitu perempuan memiliki bentuk kelamin berbeda dengan laki-laki. Perempuan bisa hamil, haid dan menyusui sedangkan laki-laki tidak. Fakta biologis inilah yang dimaksud sebagai kodrati atau suatu konstruksi (bangunan) yang given dan tidak dapat dipertukarkan satu sama lain (antara laki-laki dan perempuan).

Mansour Fakih menyatakan bahwa jender adalah suatu sifat yang melekat pada laki-laki dan perempuan yang dikonstruksi secara sosial dan kultur seperti perempuan yang dikenal lemah lembut, cantik, emosional dan keibuan sementara laki-laki dianggap kuat, rasional, jantan dan perkasa yang didalamnya terdapat tiga karakteristik. Pertama, sifat-sifat yang dapat dipertukaran. Kedua, adanya perubahan yang terjadi dari waktu ke waktu dan dari tempat ke tempat. Ketiga, jika dilihat dari kelas ke kelas masyarakat yang lain juga berbeda. Ada perempuan kelas bawah di pedesaan pada suku tertentu yang lebih kuat dibandingkan lakilaki. Berdasarkan hal tersebut Mansour Fakih berkesimpulan bahwa semua yang dapat dipertukarkan antara sifat perempuan dan laki-laki berubah dari waktu ke waktu dan berbeda dari tempat ke tempat lain, demikian juga berbeda dengan suatu kelas ke kelas yang lain. Konsep itulah yang dikenal dengan pemahaman jender. ${ }^{2}$

Menurut Elaine Showalter Jender adalah pembedaan laki-laki dan perempuan dilihat dari konstruksi sosial budaya. ${ }^{3}$ Wanita dan pria memiliki sifat yang berbeda, berdasarkan karakteristik bawaan sehingga memiliki peran yang terpisah untuk setiap jenis kelamin, wanita yang diidentikkan lebih cocok untuk menjadi ibu dan istri. ${ }^{4}$ Fakta sosial seperti mengurus rumah tangga, bercocok tanam, mengasuh anak dan berbagai aktivitas yang lain adalah konstruksi yang dapat dipertukarkan. Inilah letak perbedaan yang mendasar antara seks (jenis kelamin) dan jender kedua fakta tersebut melahirkan pembedaan laki-laki dan perempuan dalam berbagai bidang.

2 Mansour Fakih, Menggeser Konsepsi Gender dan Transformasi Sosial (Yogyakarta: Pustaka Pelajar, 1999), 8-9.

3 Elaine Showalter, Speaking of Gender (New York: Routledge, 1989), 3.

4 Rebecca Folley, "Muslim Women's Challenges to Islamic Law The Case of Malaysia," International Feminist Journal of Politics, 6 (2004), 53-84, http:/ /ipac.kacst.edu.sa/eDoc/ 2006/159807_1.pdf (diakses pada tanggal 25 Maret 2012). 
Berdasarkan hal tersebut dapat dipahami bahwa perbedaan antara lakilaki dan perempuan diwakili oleh dua konsep yaitu jenis kelamin dan ( sex ) dan jender. Perbedaan jenis kelamin menyangkut perbedaan fisik dan biologis, terutama bidang reproduksi, sedangkan jender merupakan konstruk sosiokultural. Perbedaan dalam hal pertama disebut dengan perbedaan kodrati dan bersifat nature yang tidak berubah dari masa ke masa, sedangkan perbedaan kedua bersifat relatif karena adanya sosialisasi (nurture) yang dipengaruhi oleh karakteristik masing-masing lingkungan sebagaimana laki-laki lebih kua dan rasional sedangkan perempuan cenderung lemah lembut dan emosional. ${ }^{5}$ Berdasarkan dua konsep perbedaan antara laki-laki dan perempuan tersebut, maka penulis akan memaparkan beberapa teori jender.

Teori pertama adalah teori nurture, Menurut teori nurture adanya perbedaan perempuan dan laki - laki adalah hasil konstruksi sosial budaya sehingga menghasilkan peran dan tugas yang berbeda. Perbedaan itu membuat perempuan selalu tertinggal dan terabaikan peran dan kontribusinya dalam kehidupan berkeluarga, bermasyarakat, berbangsa dan bernegara. Konstruksi sosial menempatkan perempuan dan laki - laki dalam perbedaan kelas. Lakilaki diidentikkan dengan kelas borjuis, dan perempuan sebagai kelas proletar.

Teori kedua adalah teori nature, Menurut teori nature adanya pembedaan laki - laki dan perempuan adalah kodrat, sehingga harus diterima. Perbedaan biologis itu memberikan indikasi dan implikasi bahwa diantara kedua jenis kelamin tersebut memiliki peran dan tugas yang berbeda. Ada peran dan tugas yang dapat dipertukarkan, tetapi ada yang tidak bisa karena memang berbeda secara kodrat alamiahnya. Dalam proses perkembangannya, disadari bahwa ada beberapa kelemahan konsep nurture yang dirasa tidak menciptakan kedamaian dan keharmonisan dalam kehidupan berkeluarga maupun bermasyarakat, yaitu terjadi ketidakadilan jender, maka beralih ke teori nature. Ketidakadilan jender dalam berbagai kehidupan lebih banyak dialami oleh perempuan, namun ketidak-adilan gender ini berdampak pula terhadap lakilaki, seperti dalam hal kehidupan keluarga yang tidak mungkin sebuah kapal dikomandani oleh dua nahkoda.

Talcott persons dan Bales berpendapat bahwa keluarga adalah sebuah unit sosial yang membedakan perbedaan peran suami istri untuk saling melengkapi dan saling membantu satu sama lain. Keharmonisan hidup hanya dapat diciptakan jika terjadi pembagian peran dan tugas yang serasi antara perempuan dan laki-laki dan hal tersebut dimulai sejak dini melalui pola pendidikan dan pengasuhan anak dalam keluarga. ${ }^{6}$

5 Zaitunah Subhan, Rekonstruksi Pemahaman Jender dalam Islam, Agenda Sosio-Kultural dan Politik Peran Perempuan (Ciputat: el-Kahfi, 2002), 16.

6 Talcott Persons and Robert F. Bales, Family Socialization and Interaction Process (Routladge: Kagan Paul, 2000), 36. 
Teori Ketiga adalah Equilibrium. Disamping kedua aliran tersebut terdapat kompromistis yang dikenal dengan keseimbangan (equilibrium) yang menekankan pada konsep kemitraan dan keharmonisan dalam hubungan antara perempuan dengan laki - laki. Pandangan ini tidak mempertentangkan antara kaum perempuan dan laki - laki, karena keduanya harus bekerja sama dalam kemitraan dan keharmonisan dalam kehidupan keluarga, masyarakat, bangsa dan Negara. Untuk mewujudkan gagasan tersebut, maka dalam setiap kebijakan dan strategi pembangunan agar diperhitungkan kepentingan dan peran perempuan dan laki - laki secara seimbang.

Hubungan diantara kedua elemen tersebut bukan saling bertentangan tetapi hubungan komplementer guna saling melengkapi satu sama lain. R.H. Tawney menyebutkan bahwa keragaman peran apakah karena faktor biologis, etnis, aspirasi, minat, pilihan, atau budaya pada hakikatnya adalah realita kehidupan manusia. Hubungan laki - laki dan perempuan bukan dilandasi konflik dikotomis, bukan pula struktural fungsional, tetapi lebih dilandasi kebutuhan kebersamaan guna membangun kemitraan yang hamonis, karena setiap pihak memiliki kelebihan sekaligus kelemahan yang perlu diisi dan dilengkapi pihak lain dalam kerjasama yang setara.

Teori keempat adalah teori psikoanalisa'identifikasi, teori ini pertama kali diperkenalkan oleh Sigmund Freud (1856-1939). Teori ini mengungkapkan bahwa perilaku dan kepribadian laki-laki dan perempuan sejak awal ditentukan oleh perkembangan seksualitasn. Freud menjelaskan kepribadian seseorang tersusun atas tiga struktur yaitu $i d$, ego, dan superergo. Tingkah laku seseirang menurut Freud ditentukan oleh interaksi ketiga struktur ini.

Teori kelima adalah teori fungsionalis struktural. Teori ini berangkat dari asumsi bahwa suatu masyarakat terdiri atas berbagai bagian yang saling memengaruhi. Teori ini mencari unsur-unsur mendasar yang berpengaruh di dalam suatu masyarakat, mengidentifikasi fungsi setiap unsur dan menerangkan bagaimana fungsi unsur-unsur tersebut di dalam masyarakat.

Menurut Lips ada beberapa unsur pokok dalam teori fungsionalis struktural yang menjadi kekuatan teori ini yaitu, kekuasaan dan status. Kekuasaan yang lebih besar yang dimiliki laki-laki dan status yang lebih tinggi dari perempuan menjadikan dominasi laki-laki dan subordinasi perempuan dianggap wajar di dalam masyarakat. Perempuan dinilai berpenampilan dan berprilaku lemah lembut, sementara laki-laki berpenampilan dan berperilaku tegar dan jantan karena hal tersebut laki-laki memiliki kekuasaan dan status lebih tinggi. ${ }^{7}$ Pola kekuasaan dan status ini berpengaruh secara universal di dalam masyarakat. Tidak sedikit kebijakan dan peraturan lahir diatas persepsi tersebut dan tidak heran kalau di dalam masyarakat muncul ideologi jender yang berupaya meninjau secara mendasar berbagai kebijakan dan peraturan yang dinilai tidak berwawasan

7 Hilary M. Lips, Sex and Gender: An Introduction (London: Mayfield Publishing Company, 1993), 4. 
jender. Selain kekuasaan dan status komunikasi non verbal juga merupakan unsur pokok dalam teori fungsionalis struktural.

Komunikasi antara laki-laki dan perempuan dalam masyarakat juga dianggap sebagai kemampuan lebih bagi laki-laki dan kemampuan kurang bagi perempuan hal tersebut disebabkan karena laki-laki lebih memungkinkan untuk menegur sapa perempuan. Penilaian bahwa perempuan tidak memiliki kekuasaan yang memadai cenderung merendahkan perempuan. Perempuan dengan subordinasinya menampilkan diri dengan serba hati-hati. Sementara laki-laki dengan otoritas yang dimilikinya menampilkan dirinya secara terbuka. Lakilaki lebih dimungkinkan untuk melakukan relasi awal terhadap perempuan daripada sebaliknya. Situasi seperi ini sangat berpengaruh dalam relasi jender, karena dengan demikian skor laki-laki akan lebih unggul dalam penentuan norma-norma dalam kehidupan masyarakat.

Norma-norma yang dijadikan ukuran dalam menentukan lazim atau tidaknya sesuatu adalah norma yang ditentukan oleh laki-laki, seperti pernyataan sinis yang diberikan oleh Carol Tavris dalam bukunya Mismeasure of Women., dalam buku tersebut tavris menyatakan bahwa laki-laki adalah tolak ukur segala sesuatu (man is the measure of all thing) selain itu Tavris juga menyatakan bahwa laki-laki dianggap manusia normal (normal human being) dan perempuan dianggap abnormal karena ia berbeda dengan laki-laki. Hal tersebut menurut Tavris menyebabkan perempuan bukan saja menerima status subordinasi tetapi juga terjadi feminisasi kemiskinan dan maskulinisasi kekayaan. ${ }^{8}$

Unsur pokok lain dalam teori fungsionalis struktural adalah pembagian kerja. Relasi kuasa dan status yang berbeda antara laki-laki dan perempuan menjadi dasar dalam pembagian kerja. Masyarakat tradisional mengenal pembagian kerja secara seksual, laki-laki sebagai pemburu (bunter) dan perempuan sebagai pengasuh (nurturer), hal yang sama juga dijumpai pada masyarakat modern misalnya dalam dunia bisnis perempuan diarahkan menjadi sekretaris dan laki-laki diarahkan menjadi pemimpin, dalam dunia sains perempuan sebagai operator laboratorium dan laki-laki sebagai saintis. Urusanurusan produktif seolah-olah menjadi tugas laki-laki dan urusan reproduksi dan kerumahtanggaan adalah tugas perempuan. Pembagian kerja tetap saja tidak bisa menghilangkan pengaruh faktor perbedaan biologis. ${ }^{9}$

Teori jender yang selanjutnya adalah teori konflik. Teori konflik terkadang diidentikkan dengan teori Mark karena bagitu kuat pengaruh Karl Marx didalamnya. Teori ini berangkat dari asumsi bahwa dalam suasana suatu masyarakat terdapat beberapa kelas yang saling memperebutkan pengaruh dan kekuasaan. Siapa yang memiliki dan menguasai sumber-sumber produksi dan distribusi merekalah yang memiliki peluang untuk memainkan peran utama didalamnya.

8 Carol Tavris, Mismaesure of Women (New York: Touchstone, 1992), 17.

9 Hilary M. Lips, Sex and Gender: An Introduction, 52. 
Marx mengemukakan suatu gagasan menarik bahwa perbedaan dan ketimpangan jender antara laki-laki dan perempuan tidak disebabkan oleh perbedaan biologis, tetapi merupakan bagian dari penindasan dari kelas yang berkuasa dalam relasi reproduksi yang diterapkan dalam konsep keluarga. Hubungan suami istri tidak ubahnya dengan hubungan proletardan borjuis, hamba dan tuan, pemeras dan yang diperas, dengan kata lain, ketimpangan peran jender dalam masyarakat bukan karena faktor biologis atau pemberian Tuhan (divine creation), tetapi konstruksi masyarakat (social construction). ${ }^{10}$

Berdasarkan pemaparan tersebut dapat disimpulakan bahwa terdapat enam teori jender yang dapat dijadikan sebagai bahan analisis. Setelah memahami tentang teori-teori jender tersebut penulis akan memaparkan mengenai feminisme. Kata feminisme berasal dari kata femina yang artinya memiliki sifat keperempuanan. ${ }^{11}$ Feminisme merupakan sebuah gerakan pembebasan dan perlindungan hak-hak perempuan dalam masyarakat. ${ }^{12}$

Gerakan ini lahir pada abad 19, gerakan ini cukup mendapatkan perhatian dari para perempuan kulit putih di Eropa. Pada saat itu perempuan di negaranegara Eropa ingin memperjuangkan apa yang mereka sebut sebagai universal sisterhood. Pada awalnya gerakan ini memang diperlukan pada masa itu, dimana ada masa-masa pemasungan terhadap kebebasan perempuan. Sejarah dunia menunjukan bahwa secara umum kaum perempuan merasa dirugikan dalam semua bidang dan dinomor duakan oleh kaum laki-laki, khususnya pada masyarakat yang sifatnya patriarki. Dalam feminisme ada beberapa gelombang, gelombang pertama terjadi di negara Eropa, ${ }^{13}$ pada saat itu dimana kaum perempuan merasa dirugikan baik dalam bidang pendidikan sosial, maupun dalam bidang politik. Sedangkan gelombang kedua ini lahir pada tahun 1960, yaitu ditandai dengan puncaknya hak suara perempuan diikutsertakan dalam parlemen. Pada tahun 1960 inilah sebuah awal bagi perempuan untuk mendapatkan hak suara didalam parlemen dan hingga ikut serta dalam kancah perpolitikan negara.

Pada tahun 1960-an ini gerakan ini cukup mendapatkan momentum sejarah. Untuk menunjukan bahwa sistem sosial masyarakat modern dimana memiliki struktur cacat akibat budaya patriarkal yang sangat kental. Marginalisasi peran perempuan dalam berbagai aspek kehidupan, khususnya ekonomi dan politik, merupakan bukti konkret yang diberikan kaum feminis. ${ }^{14}$ Gerakan

${ }^{10}$ Myra Marx Ferre and Judith Lorber, Revisioning Gender (Oxford: Altamira Press, 2000), 17.

${ }^{11}$ Dadang S. Ansori, Membincangkean Feminisme: Refleksi Muslimah atas Peran Sosial Kaum Wanita (Jakarta: Pustaka Hidayah, 1997), 19.

12 Victoria Neufieldt, Webster's New World College Dictionary (New York: Mc Millan General Reference, 1996), 498.

${ }^{13}$ Leila Ahmed, Wanita dan Gender dalam Islam: Akar-Akar Historis Perdebatan Modern (Jakarta: PT. Lentera Basitama,2000), 10.

${ }^{14}$ Leo Agustino, Perihal Ilmu Politik: Sebuah Bahasan Memahami Ilmu Politike(Yogyakarta: Graha Ilmu, 2007), 237. 
feminisme ini berjalan terus, sekalipun sudah ada perbaikan-perbaikan, kemajuan yang dicapai gerakan ini, namun tetap saja terlihat banyak mengalami halangan.

Feminisme gelombang kedua ini merupakan suatu proyek transformasi radikal dan bertujuan untuk menciptakan dunia yang difeminiskan. Dengan adanya operasi penindasan dalam berbagai kehidupan, ketidakadilan dalam ranah politik dan kekuasaan dan kemudian hal itu menjadi kajian para feminisme gelombang kedua, karena itulah pada dekade tersebut lahir apa yang disebut dengan politik feminisme. Politik feminisme yang dimaksud dalam konteks global yaitu memperjuangkan hak ikhwal terhadap perempuan. Dalam dekade sekarang ini ada banyak aliran-aliran bermunculan dipanggung sejarah pemikiran dan praktik politik, diantaranya kita kenal dengan aliran feminisme liberal, ${ }^{15}$ feminisme radikal, feminisme marxis, feminisme anarkis, dan terakhir feminisme postmodern. ${ }^{16}$

Feminisme liberal mengintegrasikan perempuan ke dalam struktur mainstream masyarakat. Ia berakar pada teori kontrak sosial pemerintahan yang dibentuk Revolusi Amerika. ${ }^{17}$ Karya klasik yang mendasar pandanganpandangan awal feminis liberal adalah karya besar Jhon Stuart Mill dan Harriet Taylor dalam The Subjection of Women. Mill memulai gagasannya dengan argumentasi bahwa semua manusia memiliki kebebasan yang setara sehingga institusi sosial harus memberlakukannya secara sama. ${ }^{18}$ Pembebasan tuntutan kesetaraan atas perempuan didasarkan pada prinsip persamaan hak dan kebebasan yang berlaku bagi semua manusia tanpa kecuali. Menurut Mill perhatian kepada masalah-masalah perempuan adalah perluasan dari cita-cita dalam membentuk masyarakat yang egaliter.

Feminis marxis dicirian oleh pendekatannya atas ketertindasan perempuan melalui analisis kelas yang diintroduksi Marx lewat materialisme dialektis, bagi mereka penindasan perempuan adalah bagian dari penindasan kelas dalam hubungan produksi. ${ }^{19}$ Inilah yang membedakan mereka dari feminis liberal yang menempatkan analisisnya pada level individu. Feminis marxis melihat penindasan perempuan sebagai persoalan struktural sehingga analisis atas kondisi perempuan selalu diletakkan sebagai kritik atas kapitalisme pada level struktur masyarakat. Aliran marxis mulai berkembang di Jerman dan Rusia dengan menampilkan beberapa tokohnya, Seperti Clara Zetkin dan Rosa Luxemburg. ${ }^{20}$

15 Dadang S. Ansori, Membincangkan Feminisme: Refleksi Muslimah atas Peran Sosial Kaum Wanita, 24.

${ }^{16}$ Leo Agustino, Perihal Ilmu Politik: Sebuah Bahasan Memahami Ilmu Politik, 243.

${ }^{17}$ Rahmad Hidayat, Ilmu Yang Seksi, Feminisme dan Perlawanan Terhadap Teori Sosial Maskulin (Yogyakarta: Jendela, 2004), 97.

${ }^{18}$ John Stuart Mill, The Subjection of Women (Logman: Savili Edward,1955), 219.

19 Nasaruddin Umar, Argumen Kesetaraan Jender Perspektif Al-Quran (Jakarta: Paramadina, 2001), 66.

${ }^{20}$ Nasaruddin Umar, Argumen Kesetaraan Jender Perspektif Al-Quran, 65. 
Feminis radikal muncul sebagai reaksi atas kultur sexisme atau diskriminasi sosial berdasarkan jenis kelamin di Barat pada 1960-an khususnya mereka melawan kekerasan seksual dan pornografi, ajaran mereka memberi tekanan pada kekuasaan, hak istimewa, dan perkembangan psikologi laki-laki sebagai dasar relasi sosial. Feminisme radikal melihat relasi patriarki sebagai hal yang lebih fundamental daripada relasi kelas dalam menentukan kehidupan perempuan. Namun terdapat sedikit kesamaan keyakinan dengan feminisme liberal bahwa menurut ajaran feminis radikal usaha-usaha pembebasan perempuan dapat berjalan pada tingkat personal. Feminis radikal ada yang lebih ekstrem tidak hanya menuntut persamaan hak dengan laki-laki, tetapi juga persamaan seks dalam arti kepuasaan seksual juga bisa diperoleh dari sesama perempuan sehingga mentolerir praktek lesbian. ${ }^{21}$

Juliet Mitchell membedakan perspektif sosialis dari persfektif radikal, ia mengaitkan feminis sosialis dengan kerangka kerja Marxis. Perspektif sosial menyadari bahwa analisis kelas dan pendekatan ideologis gender saja tidak cukup menjelaskan kondisi perempuan apabila dilakukan secara terpisah. Feminisme sosial adalah sintesis antara analisis kelas dalam hubungan produksi ( Marxis ) dengan analisis gender dalam hubungan antar-seks ( radikal ). ${ }^{22}$

Kemunculan feminis sosialis pada tahun 1970-an berakar secara luas dari ketidakpuasan para feminis dengan pandangan klasik Marx tentang perempuan dan keluarga. Feminis sosialis berpandangan bahwa kaum pria memiliki kepentingan material tertentu dalam dominasinya terhadap perempuan dan bahwa kaum pria membangun beragam pengaturan institutional untuk mengekalkan dominasi ini. Feminis sosialis juga merupakan sintesis antara analisis kelas dalam hubungan produksi (Marxis) dengan analisis gender dalam hubungan antar seks. ${ }^{23}$

Feminis sosialis mempunyai sebuah teori epistemologi, yang menyertakan sebuah pandangan bahwa semua pengetahuan menunjukkan kepentingankepentingan dan nilai-nilai dari sebuah kelompok sosial tertentu dengan menjelaskan variasi-variasi historis dalam praktik, dan dalam kategori yang dengannya nilai-nilai dapat dipahami.

Terdapat banyak variasi teori dan gerakan dalam feminis menampilkan keberagaman ide, nilai dan perspektif, keragaman itu terjadi karena banyaknya feminis yang berangkat dari disiplin ilmu yang berbeda. ${ }^{24}$ Feminism Islam pada awalnya diadopsi dari luar masyarakat Islam, sebagian besar adalah ciptaan

${ }^{21}$ Caroline Ramazanoglu, Feminism and Contradiction (London: Routledge, 1989), 12.

22 Rahmad Hidayat, Ilmu Yang Seksi Feminisme dan Perlawanan Terhadap Teori Sosial Maskulin (Yogyakarta: Jendela, 2004), 101.

${ }^{23}$ Rahmad Hidayat, Ilmu Yang Seksi Feminisme dan Perlawanan Terhadap Teori Sosial Maskulin (Yogyakarta: Jendela, 2004), 101.

24 Al-Husain Al-Hakim, Islam and Feminism, trans. Jemal Gembala (Jakarta : Al-Huda, 2005), 26. 
para akdemisi dan peneliti feminis muslim yang hidup dan bekerja di barat. ${ }^{25}$ Dominasi sistem kehidupan sekular juga melahirkan ide-ide turunan semisal liberalisme dan egalitarisme yang mengungkung kehidupan mereka. Adapun kompleksitas persoalan seputar isu disparitas jender yang juga dialami perempuan muslim dan adanya kejenuhan yang luar biasa terhadap sistem nilai yang dianggap tak mampu mengadopsi kepentingan perempuan. ${ }^{26}$

Struktur patriartikal pada masyarakat secara efektif disuburkan dan dilanggengkan melalui keluarga Arab. Dalam bentuk khasnya, keluarga Arab sangat patriarkal dan hierarkis dalam hubungannya dengan usia dan jenis kelamin, orang tua maupun pria mempunyai otoritas atas kaum muda dan perempuan, ayah mempunyai posisi kunci dalam kekuasaan dan wewenang. Ia mengharapkan dan memastikan kesetiaan tanpa kritik dari istri dan anak-anaknya serta boleh menghukum secara keras setiap bentuk pembangkangan. ${ }^{27}$

Pada struktur ini jender menjadi sangat terpolarisasi, pria harus kuat dan dominan, sedangkan perempuan harus lemah sangat tergantung pada pria dan sangat rendah. Dengan demikian posisi bawah perempuan dalam keluarga Arab tradisional ditunjang oleh adat dan hukum yang masih ditaati oleh mayoritas penduduk. $^{28}$

Semuanya berubah setelah Muhammad Abduh mengadakan pembaharuan hukum keluarga Mesir salah satu kritikan Muhammad Abduh mengenai poligami menurutnya asas yang ada dalam Al-Quran adalah asas monogami karena dalam Al-Quran dijelaskan bahwa syarat utama poligami adalah harus berlaku adil dan menurut Abduh tidak ada orang yang dapat berlaku adil oleh karena itu asas yang terkandung dalam Al-Quran adalah monogami. ${ }^{29}$

Tokoh selanjutnya adalah Qosim Amin juga merupakan tokoh pembaharu Mesir ( pemikir asal Mesir, hidup antara 1863-1908) Qosim Amin menulis buku berjudul Tahrir al-Mar'ah dan al-Mar'ah al-Jadidah yang disebut-sebut sebagai tonggak gerakan perempuan di dunia Islam. Qasim secara ekspresif mengungkapkan kekagumannya atas prestasi perempuan barat yang telah berhasil memperoleh kebebasan dan independensinya, sehingga mereka bisa keluar dari status inferior yang mereka miliki sebelumnya.

Dia memuji tingginya rasa hormat laki-laki Barat pada kebebasan perempuan yang antara lain ditunjukkan oleh pemberian kebebasan perempuan yang berusia 20 tahun untuk meninggalkan keluarga mereka, bagaimana seorang

${ }^{25}$ Haideh Moghisi, Feminisme dan Fundamentalisme Islam (Yogyakarta: LKiS, 2005), 170.

${ }^{26}$ Najmah Saidah dan Husnul Khatimah, Revisi Politik Perempuan Bercermin Pada Shahabiyat (Bogor: Pustaka Utama, 2003), 63.

${ }^{27}$ Najmah Saidah dan Husnul Khatimah, Revisi Politik Perempuan Bercermin Pada Shahabiyat (Bogor: Pustaka Utama, 2003), 64.

${ }^{28}$ Mai Yamani, Feminism and Islam : Legal and Literary Perspectives, trans. Purwanto (Bandung: Nuansa Cendikia, 2000), 125.

${ }^{29}$ John L Esposito, Women in Muslim Family Law (New York: Cyracuse University Press, 1982), 51. 
suami memberikan kebebasan kepada isterinya untuk memiliki teman yang bukan suaminya, serta bagaimana perempuan bebas untuk bercampurbaur dengan laki-laki, Qasim percaya bahwa kebebasan merupakan sumber yang bagus bagi umat manusia dan menjadi pondasi untuk menuju kemajuan. ${ }^{30}$

Pada perkembangan selanjutnya, pengaruh pemikiran mereka berkembang melewati batas-batas negara dan mengilhami lahirnya feminis-feminis muslim kontemporer yang concern memperjuangkan kebebasan perempuan, terutama melalui pendekatan pragmatis atas kajian teks-teks keagamaan dan pembaharuan hukum yang dilakukan keluarga muslim modern melalui dua model yaitu intra doctrinal reform dan extra doctrinal reform. ${ }^{31}$ Di antara nama-nama mereka adalah Fatimah Mernissi (Maroko), Riffa'at Hassan (Pakistan), Amina Wadud Muhsin, Nawal al-Sadawi (Mesir), Asghar Ali Engineer (Pakistan), Masdar Mas'udi dan Nasaruddin Umar (Indonesia).

Terdapat tiga pola respon masyarakat Islam tentang feminisme, pertama, Feminisme apologetic. Aliran ini merupakan aliran yang mencoba mengadaptasikan agama agar cocok dengan prinsip-prinsip feminis. Namun yang perlu digarisbawahi bahwa aliran ini memberi porsi yang lebih besar pada prinsipprinsip feminis. Dalam pengertian lain, aliran ini menerima feminisme sebagai aliran yang tak terbantahkan. Kedua, Feminisme Reaksioner (defensive). Aliran ini merupakan aliran yang memandang bahwa perempuan sudah mendapatkan kesetaraan dan posisi yang terhormat dalam tradisi Islam. Sehingga dengan demikian tidak dibutuhkan lagi adanya reformasi dalam hal-hal yang terkait dengan wanita. Ketiga, Pendekatan Strukturalis. Pendekatan ini melihat hak-hak dan posisi perempuan dalam keseluruhan konteks struktur masyarakat dan menghindari perpecahan masyarakat dalam terminologi "feminisme" atau "maskulinisme". ${ }^{32}$ Pendekatan ini menghubungkan antara pria dan wanita dengan tanggung jawab sosial dan individual (tentunya dengan memperhatikan ajaran-ajaran religius), tanpa adanya tendensi monoseksual.

Pada hakikatnya tidak ada masalah di dunia Islam dalam hal gender. Islam menempatkan dan memposisikan perempuan dan laki-laki secara adil. Keduanya sama-sama memiliki kewajiban dan amanat. Keduanya dibebankan tanggung jawab yang sama berdasarkan sarana-sarana sempurna yang dimiliknya. Kendati demikian, dalam perkembangannya ada kesalahpahaman yang menyebabkan seakan-akan konsep kemanusiaan dalam Islam antara laki-laki dan perempuan berjalan berat sebelah. Untuk itu perlu diperjelas kembali bagaimana sebenarnya pandangan Islam terhadap perempuan. Secara umum,

${ }^{30}$ Qasim Amin, Sejarah Penindasan Perempuan Menggugat Islam laki-laki Menggugat Perempuan Baru, terj. Ircisod (Yogyakarta: Pustaka Setia, 2003), 79-80.

31 Tahir Mahmood, Family Law Reform In The Muslim World (New Delhi: The Indian Law Institute, 1972), 267.

32 Ali Hossein Hakeem, et. al. Membela Perempuan; Menakar Feminisme dengan nalar Agama (Jakarta: Al-Huda, 2005), 34. 
Islam memandang perempuan dalam dua konsep dasar, yakni; pertama, sisi persamaan dan kedua, sisi perbedaan.

Pertama, sisi persamaan, yakni melihat persamaan laki-laki dan perempuan dari sisi esensi kemanusiaan maksudnya perempuan sebagaimana halnya lakilaki dibedakan dari makhluk lainnya selain itu juga bahwa laki-laki dan perempuan sama-sama berasal dari unsur yang satu (ruh). Lebih lanjut, kesamaan dalam hal-hal ini berimplikasi pada tanggung jawab yang dibebankan kepada keduanya, yakni meliputi tanggung jawab terhadap diri, masyarakat, dan Tuhan sebagai Penciptanya. ${ }^{33}$

Kedua sisi perbedaan, yakni membedakan manusia dari sisi jenisnya, yakni laki-laki dan perempuan. Secara implikatif, hal ini berdampak bagi adanya pembagian peran antara keduanya. Kendati demikian, pembagian ini tidak berarti memperlemah posisi salah satunya, tetapi justru dapat saling memberikan kontribusi. Inilah yang kemudian membagi peran perempuan dan laki-laki dalam kehidupan keluarga dan bermasyarakat.

Dua pembagian di atas sangat kentara sekali di saat zaman Nabi Muhammad SAW. Dari perspektif Islam, kedatangan Nabi Muhammad 14 abad yang lalu adalah rahmat bagi seluruh alam, tidak terkecuali bagi kaum perempuan yang ketika itu merupakan golongan tertindas dan lemah. Kalau menilik sejarah kemunculannya dan juga nilai-nilai yang tertuang dalam teksteks sucinya, Islam justru adalah agama yang menghormati dan menjunjung tinggi perempuan. Lihat saja apa yang dilakukan Nabi Muhammad saw di masa hidupnya. Dialah yang mengangkat posisi rendah dan hina perempuan di Jazirah Arab ke posisi yang seharusnya. Islam yang dibawanya mendudukkan wanita sederajat dengan laki-laki.

Islam juga memberikan peran dan hak-hak yang sebelumnya tidak didapat oleh perempuan di masa pra-Islam. Hak-hak itu meliputi hak untuk berpendapat, hak untuk memperoleh warisan, hak untuk memperoleh pendidikan dan hak untuk terlibat dalam ranah publik, entah itu bekerja maupun berpolitik (memilih dan dipilih). Memang untuk hak yang terakhir ini masih banyak perdebatan, namun tak bisa disalahkan jika ada yang berpendapat demikian. Hal ini tentu saja tergantung dari sejauh mana dalil-dalil yang diberikan itu dapat mendukung pernyataan di atas.

Para cendekiawan, baik dari modernis maupun ulama hampir sepakat bahwa pencampuradukan antara agama (Islam) dengan tradisi, kejumudan cara berpikir, serta berkuasanya pemerintahan yang despotik adalah sumber dari anggapan bahwa Islam adalah agama yang tidak adil atau diskrimantif terhadap perempuan. Sehingga tak heran jika kemudian, para feminis atau pun modernis misalnya mencoba untuk memahami atau menafsirkan ulang teks-teks yang berkaitan dengan wanita dalam Islam.

\footnotetext{
${ }^{33}$ Sachito Murata, The Tao of Islam (Bandung: Mizan, 1996), 32.
} 


\section{B. Sanksi dalam Hukum Keluarga dan Relasinya dengan Keadilan Jender}

With a marriage contract a woman comes under her husband'sThe contract does not create joint ownership of resources: the husbanAmong the default rights of the husband is his power to controNushuz merupakan suatu konsep dalam al-quran mengenai pembangkangan seorang istri terhadap kekuasaan suaminya. Ketidakpatuhan wanita dianggap begitu menakutkan di dunia muslim karena implikasi-implikasinya yang sangat besar. Mereka mengacu pada bahaya paling ditakuti dalam Islam sebagai suatu psikologi kelompok; individualisme.

Fatimah mernisi menjelaskan dalam buku bahwa nushuz merupakan pemberontakan wanita terhadap suaminya yang diibaratkan juga dengan pemberontakan terhadap ummah, terhadap nalar, tatanan dan bahkan tuhan. Menurutnya nushuz diibaratkan dengan pemberontakan kaum wanita yang dianggap menimbulkan berbagai pertanyaan berkaitan dengan individualisme. ${ }^{34}$

Kebebasan individu, yang diwakili oleh pemberontakan kaum wanita, menentang seluruh gagasan mengenai komunitas sebagai hak yang utama, tetapi karena individualisme juga mengganggu dari sisi lain yang bisa menjadi ancaman jika diungkapkan oleh kaum wanita. Dalam rumah tangga kaum pria menguasai kaum wanita. Dalam ruang ini nushur ${ }^{35}$ inovasi, atau pemberontakan kaum wanita dianggap sebagai ancaman yang dapat mengubah hukum, hak istimewa dan hierarki. ${ }^{36}$ Berdasarkan definisi tersebut dapat disimpulkan bahwa nusbuz merupakan pelanggaran komitmen bersama terhadap kewajiban kedua belah pihak baik istri maupun suami dalam rumah tangga meskipun Fatimah Mernissi mengaitkan nushuz dengan pemberontakan wanita terhadap ummah tetap saja nushuz merupakan pembangkangan istri terhadap suaminya dalam tatanan rumah tangga.

Sanksi yang diterima istri pada saat istri nushuz adalah sanksi psikologis dan intervensi fisik. Kategori pertama dalam sanksi nushuz adalah sanksi psikologis, yaitu pembebanan penderitaan kejiwaan yang termasuk kedalam

${ }^{34}$ Fatimah Mernissi, Women's Rebellion and Islamic Memory (New York: Zed Books,1996), 204.

${ }^{35}$ Kata nushu₹ merupakan bentuk mashdar (akar kata) dari kata, نشز ينثز yang mempunyai arti tanah yang terangkat tinggi ke atas. Jalal al-din Muhammad Ibnu Makram Ibnu Manzhur, Lisan Al-'Arab (Kairo: Dar al Mishriyah li al 'Ta'lif wa al Tarjamah, tt),637. Ahmad Warson al-Munawwir dalam kamusnya memberi arti nushuz dengan arti sesuatu

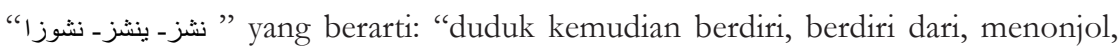
menentang atau durhaka. Lihat Ahmad Warsan Munawir, Al-Munawir Kamus Arab Indonesia (Yogyakarta: Pustaka Progresif, 1994), 1517. Sedangkan dalam kajian terminologis, nushuz dimaknai dengan tidak tunduk kepada Allah SWT untuk taat kepada suaminya Lihat Zaitunah Subhan, Menggagas Fiqh Pemberdayaan Perempuan (Jakarta: El-Kahfi, 2008), 289. 
sanksi psikologis ini diantaranya diberi nasihat, pisah tempat tidur dan kehilangan nafkah iddah sebagai berikut:

- Diberi Nasihat

Nasihat merupakan upaya persuasif dan langkah edukasi pertama yang harus dilakukan seorang suami ketika menghadapi isteri yang nushuz. Hal ini ditunjukan sebagai cara perbaikan secara halus untuk menghilangkan semua kendala-kendala yang mengusik hubungan rumah tangga. Hampir seluruh ulama berpendapat sama, yakni, amat pentingnya cara memberi nasihat ini, sehingga hal ini menjadi urutan pertama dalam upaya menyelesaikan permasalahan nushur: ${ }^{37}$

Pada tahap ini, pasangan suami istri menyediakan waktu untuk membahas perilaku salah satu pihak atau masing-masing dari mereka yang dapat mempengaruhi ketenangan rumah tangga. ${ }^{38}$ Selain itu Suami hendakanya mengingatkan kembali tentang ikatan janji yang kuat di antara mereka yang tidak boleh pudar begitu saja oleh hati maupun aqal serta disampaikan akibat buruk yang akan menimpa hubungan mereka apabila ia tetap dan meneruskan jalannya. ${ }^{39} \mathrm{Hal}$ ini senada dengan apa yang diungkapkan oleh Abu Bakar AlJassas bahwa menasihati yaitu menakut-nakuti isteri dengan siksaan Allah. ${ }^{40}$ Namun jika persoalan yang mereka hadapi terasa semakin berat dan diantara mereka tidak ada lagi pihak yang mau memulai untuk mengambil inisiatif damai secara persuasif ini, maka mereka dapat mendatangkan mediator pihak lain sebagai perwakilan mereka guna mendiskusikan persoalan yang sedang terjadi. ${ }^{41}$

Terciptanya suasana musyawarah dan demokratis dalam rumah tangga pada ahirnya akan menjadikan pasangan suami-isteri memperoleh hak secara berimbang dan sejajar, serta dapat memunculkan sikap saling mengerti latar belakang masing-masing dan diri sendiri. Saling menerima kelebihan dan kekurangan pasangannya. Saling menghormati perasaan, keinginan dan pribadi masing-masing. ${ }^{42}$ Berdasarkan pemaparan tersebut dapat disimpulkan bahwa menasihati merupakan jalan yang sangat dianjurkan pertama kali, tentunya dengan memberikan nasihat atau peringatan yang mengarahkan kepada pemulihan hubungan dalam rumah tangga, dalam hal ini suami dituntut bijaksana baik perkataan maupun perbuatan, tegas bukan berarti kasar.

${ }^{36}$ Fatimah Mernissi, Women's Rebellion and Islamic Memory, 205.

37 Syauqi Al-Qadrani, Nushuz. (Jakarta: Gema Insani Press, 2004), 46.

38 Ali Husain Al-Hakim, Islam and Feminism: Theory, Modelling and Applications, 56.

${ }^{39}$ Muhammad Usman al-Khasit, Sulitnya Berumah Tangga: Upaya Mengatasinya Menurut al-Qur'an dan Hadis, ilmu Pengetabuan (Jakarta: GIP, 1994), 78.

${ }^{40}$ Abi Bakr Ahmad ibn 'Ali Razi Al-Jassas, Ahkam Al-Qur'an (Bairut: Dar al-Kutub alAlamiyah, 1415 H/1993 M.), II: 238.

${ }^{41}$ Abu Hamid Muhammad bin Muhammad al-Ghazali, Ihya' 'Ulum ad-Din (Beirut: Dar al-Fikr, 1975), II: 15.

${ }^{42}$ Khoiruddin Nasution, Islam, Tentang Relasi Suami dan Isteri, 60. 


\section{- Pisah Tempat Tidur}

Para ulama berbeda pendapat dalam menafsirkan tahap kedua ini, sebagian ada yang berpendapat bahwa suami hanya memalingkan mukanya di tempat tidur. Sedangkan sebagian yang lain berpendapat bahwa suami meninggalkan tempat tidurnya dan tidur di tempat lain.

Sebagian besar ahli fiqih menyatakan bahwa yang dimaksud meninggalkan istri dari tempat tidur adalah memalingkan tubuh. ${ }^{43}$ Mengenai hal tersebut tidak ada ketentuan yang menjelaskan secara terperinci sampai dimana batasan-batasan memalingkan atau meninggalkan istri di tempat tidur, walaupun ada sebagian ulama' yang berpendapat bahwa hijr yang dilakukan suami itu boleh dilakukan asal tidak melebihi tiga hari.

Sedangkan yang lain berpendapat dengan menganalogikannya pada batas hak ila' yaitu empat bulan. Meskipun demikian perlakuan hijr suami, dapat dikategorikan sebagai bentuk kekerasan seksual terhadap isteri, karena apabila dikembalikan pada tujuan asal perkawinan yang salah satunya adalah untuk pemenuhan kebutuhan biologis, maka sikap tidak perduli terhadap kebutuhan biologis pasangannya yang ditunjukkan dengan cara menjahui ranjangnya dan menghindari dalam berhubungan seks merupakan tindakan yang salah mengingat kebutuhan itu tidak hanya merupakan hak suami saja namun juga merupakan hak isteri. ${ }^{44}$ Menurut Muhammad Abduh langkah kedua ini, yaitu menjauhi isteri dari tempat tidurnya merupakan sanksi dan pelajaran yang diberikan kepada isteri yang sangat mencintai suami dan amat menderita bila dikucilkan.

Menjauhi tempat tidur bukan berarti harus meninggalkan tempat tidur atau kamar tidur untuk tidak tidur bersama isteri, karena itu malah akan dapat menambah kebandelan isteri. Sebab dengan masih tidur bersama isteri walaupun tidak mencampurinya diharapkan akan mampu menetralisir emosi suami dan isteri, sehingga jiwa menjadi tenang dan pertengkaran dapat diatasi. Oleh karena itu pemahaman tentang langkah kedua yang selama ini lebih dipahami sebagai hak suami untuk 'menghukum' isterinya yang nushuz dengan menjauhinya, mendiamkannya dan tidak melakukan hubungan badan dengannya merupakan pemahaman yang berlebihan. Sebab ketika tahap ini diartikan seperti itu maka tentu saja persoalan yang ada di antara suami-isteri tidak akan selesai bahkan sebaliknya akan berlarut-larut ditambah lagi perasaan kecewa isteri karena kebutuhan psikologis dan biologisnya tidak terpenuhi oleh sikap suami yang berusaha menjahuinya.

- Kehilangan Nafkah karena Dicerai/Talak

Sanksi lain bagi istri yang nushuz dapat berupa talak. Talak merupakan sanksi bagi istri yang nushuz karena ketika suami mentalak istrinya yang nushuz. maka istri akan kehilangan nafkah iddah dan hal tersebut merupakan sanksi

43 Ali Husain Muhammad Makki al-Amili, At-Talaq khoti'atu man? (Beirut: Mu'assasah Al-urwah al-wutsqa, t.th), 154.

${ }^{44}$ Khoiruddin Nasution, Islam, Tentang Relasi Suami dan Isteri, 40. 
bagi istri. Adapun pengertian talak menurut bahasa melepaskan ikatan dan membebaskan, secara terminologi para ulama mengemukakan rumusan yang berbeda mengenai pengertian talak. Said sabiq dalam figh al-sunnah memberikan pengertian tentang talak yaitu melepaskan tali perkawinan dan mengakhiri hubungan suami istri. ${ }^{45}$ Sedangkan Al-Jaziri dalam kitabnya al-fiqh 'ala al-madhabib al-'Arba'ah menyatakan bahwa talak adalah menghilangkan ikatan perkawinan atau mengurangi pelepasan ikatannya dengan menggunakan kata-kata tertentu. ${ }^{46}$

Definisi lain dapat dilihat dalam kitab Kifayat al-Akhyar yang menjelaskan bahwa talak merupakan sebuah nama untuk melepaskan ikatan nikah dan talak merupakan lafadz jahiliyah yang setelah Islam datang menetapkan lafadz tersebut sebagai kata untuk melepaskan nikah. ${ }^{47}$ Talak merupakan salah satu bentuk pemutusan hubungan ikatan suami istri karena sebab-sebab tertentu yang tidak memungkinkan bagi suami istri meneruskan hidup berumah tangga. Penyebutan nama talak merupakan istilah lama yang dikenal sejak zaman jahiliyah yang kemudian setelah Islam datang talak dikenal sebagai bagian dari shariah. ${ }^{48}$ Berdasarkan definisi tersebut dapat disimpulkan bahwa talak adalah hilangnya ikatan perkawinan yang berakibat hilangnya kehalalan bagi kedua belah pihak yaitu suami dan istri. Secara esensial bercerai berarti kufur terhadap nikmat Allah, maka bercerai menjadi haram jika tidak ada alasan yang jelas akan tetapi apabila keadaan darurat maka perceraian diperbolehkan.

Talak yang dijatuhkan suami ketika istri yang nushuzadalah talak bain shugro yang berimplikasi terhadap hilangnya nafkah iddah bagi istri. Nafkah merupakan kewajiban suami terhadap istri yang timbul sejak terlaksananya akad sah pernikahan antara dirinya dan isterinya itu. ${ }^{49}$ kewajiban suami untuk memberikan nafkah kepada keluarga (anak dan isteri) merupakan salah satu sebab kepemilikan suami terhadap otoritas kepemimpinan rumah tangga..$^{50}$

${ }^{45}$ Said sabiq, Fiqh Al-Sunnah (Libanon: Dar al-Fikr, 1981), Jilid 2, 206.

${ }_{46}$ Al-Syirazi, al-Fiqh 'ala al-Mazahib al-'Arba'ah, 278.

${ }^{47}$ Taqiyuddin, Kifayat al-Akhyar (Kairo: Isa al-babi al-halabi, 84

${ }^{48}$ Muhammad bin Ismail bin Salah al-San'ani, Subul al-Salam Sharb Buluq al-Maram (T.tp, Cetakan Jamiah al-Imam Muhammad Ibnu Sa’ud al-Islamiyah, 1408 H), Juz 3, 302.

49 al-Zuhaili, al-Fiqh., VII: 769-770. Bahkan jika suami tidak dapat memberikan nafkah hingga beberapa waktu kemudian, maka nafkah yang belum terbayar hingga beberapa waktu tersebut tetap menjadi kewajibannya yang harus dibayarkan di kemudian harinya, atau yang disebut dengan nafkah terhutang. Jadi dengan adanya nafkah yang terhutang itu tidak menjadikan gugurnya kewajiban nafkah suami kepada isterinya. Lihat Ibn alQayyim al-Jauziyyah, Zad al-Ma'ad (Bairut: Muassasah al-Risalah, 1994), V: 505 dan 508.

${ }^{50}$ Fithriyah Wardie Murdani, "Kewajiban dan Hak Suami Isteri dalam Keluarga Islam” dalam Al-Insan, No. 3, Vol. 2, Tahun 2006 (Jakarta: Lembaga Kajian dan Pengembangan Al-Insan, 2006),19. 
Nafkah yang ditanggung suami juga tidak dapat gugut atau terhapus begitu saja dengan kefakiran suaminya. Berdasarkan logika fiqih, karena laki-laki atau suami telah memiliki hak untuk menahan isteri (untuk tetap tinggal bersamanya), maka sudah seharusnya laki-laki atau suami mendapatkan beban kewajiban nafkah kepada isteri, sebagai ganti atau harga dari penahanan tersebut.

Oleh karena itu ketika istri nushuzmaka hilanglah kewajiban nafkah suami terhadap istri, karena suami tidak lagi dapat menahan istrinya untuk tinggal di rumah bersamanya. Dan hak tersebut merupakan salah satu sanksi yang bisa dijatuhkan kepada istri yang nushuz sebagai sebuah pelajaran terhadap istri yang melakukan kelalaian terhadap kewajibannya.

Kategori kedua dari sanksi nushuz adalah intervensi fisik. Intervensi fisik yang dimaksud disini adalah memukul, inilah tahapan intervensi fisik setelah tahap pertama dan kedua dilakukan. Dalam masalah pemukulan ini fuqaha' mendefinisikannya dengan pengertian yang masih umum, yaitu suatu perbuatan yang menyakitkan badan, baik meninggalkan bekas atau tidak, dengan mengunakan alat atau tidak. ${ }^{51}$ Kalau diteliti lebih lanjut sebenarnya kalimat dharaba berasal dari fi'il madi daraba - yadribu yang di dalam Al-Qur'an kata ini mempunyai banyak arti:

- Jika dalam Ayat واضربوهن jelas fi'il amr yang berasal dari fi’il madhi bermakna pukul artinya seseorang yang menjatuhkan sesuatu dari anggota tangannya kepada orang lain.

• Untuk Ayat وضرب الله مثنل kalimat fi'il madi ini bukan arti pukul, namun mempunyai arti i'tibar (perumpamaan).

· Jika untuk Ayat عن اضرب بعصاك الحجر artinya fi'il amar yang tersebut sama artinya dengan pukul, hanya bedanya dengan suatu alat.

Surat an-Nisa' (4): 34 yang sering disebut sebagai ayat nushuz digunakan sebagai kunci perdebatan tentang konstruksi jender dan kekerasan terhadap perempuan ayat tersebut juga sering dijadikan dasar pembenaran kekerasan terhasap istri. ${ }^{52}$

Fuqaha yang berpendapat tentang dibolehkannya melakukan pemukulan, mereka mendasarkannya pada surat an-Nisa' (4): 34 yang memiliki kronologi historis sebagaimana diriwayatkat oleh az-Zamakhsyari tentang peristiwa Sa'ad ibn Ar-Rabi' ibn 'Amr dan isterinya Habibah binti Zaid ibn Abi Zuhair sebagai peristiwa yang melatarbelakangi turunnya Ayat tersebut. Diriwayatkan bahwa Habibah nushuz terhadap suaminya Sa'ad, salah seorang pemimpin Ansar. Lalu Sa'ad memukul Habibah, puteri Zaid ibn Zuhair ini mengeluhkan perlakuan

51 A Syauqi Al-Qadrani, Nushuz, 57.

52 Sa'diyah Shaikh, “Exegetical Violence: Nushuz in Qur'anic Gender Ideology," Journal for Islamic Studies 17 (1997), 49-73, http:/ /www.sistersinislam.org.my/ files/downloads/ saadiya/pdf (diakses pada tanggal 23 Maret 2011). 
suaminya kepada ayahnya. Sang ayah kemudian mengadukan hal itu kepada Nabi. Nabi menganjurkan Habibah membalas dengan setimpal.

Berkenaan peristiwa itulah turun surat an-Nisa' Ayat 34 ini. Setelah Ayat turun, Nabi bersabda: "Kita menginginkan satu cara, Allah menginginkan cara yang lain. Yang diinginkan Allah itulah yang terbaik". Selain hadith tersebut sebenarnya masih terdapat ayat lain yang cukup beralasan untuk dijadikan pembanding dalam mengkaji persoalan pemukulan terhadap isteri ini yaitu surat sad ayat 44 .

Sebagaian ulama berpendapat dengan berdasarkan ayat tersebut tentang dibolehkannya suami memukul isterinya dalam rangka memberi pelajaran. Seperti halnya nabi Ayyub yang memukul isterinya karena telah melanggar hakhak suami..$^{53}$

Ayat tersebut menunjukkan tentang dibolehkannya pemukulan terhadap isteri dengan batasan tidak sampai melampaui batas sebagai instrument pendidikan, dalam arti lain, dibolehkanya tindakan tersebut bukan berarti tanpa adanya unsur kemakruhan atau suatu yang lebih baik jika harus dihindari. Walaupun secara tekstual syari'at membolehkan suami memukul isteri yang nushuz akan tetapi harus diperhatikan penjelasan Rasulullah dalam menetapkan syarat-syarat diperbolehkannya tindak pemukulan tersebut, yaitu tidak boleh dimaksudkan untuk menghina derajat atau martabat wanita, menyakiti isterinya dan tidak boleh dilakukan dengan motifasi menggangu atau tindakan balas dendam..$^{54}$ Dalam hal pemukulan, para mufassir sepakat bahwa pemukulan yang dibenarkan adalah pukulan yang tidak menyakitkan pukulan yang tidak melukai, tidak mematahkan tulang dan tidak merusak muka.

Menurut Muhammad 'Ali as-Sabuni dan Wahbah az-Zuhaili, bagian yang harus dihindari dalam tahap pemukulan adalah bagian muka, karena muka adalah bagian tubuh yang dihormati. Bagian perut dan bagian lain yang dapat menyebabkan kematian, karena pemukulan ini bukan bermaksud untuk mencidrai apalagi membunuh isteri yang nushuz melainkan untuk mengubah

${ }^{53}$ Nabi Ayyub a.s. menderita penyakit kulit beberapa waktu lamanya dan dia memohon pertolongan kepada Allah SW'T. Allah memperkenankan doanya dan memperkenankan agar dia menghentakkan kakinya ke bumi. Ayyub a.s. mentaati perintah itu maka keluarlah air dari bekas kakinya atas petunjuk Allah, Ayyub a.s. pun mandi dan minum dari air itu, sehingga sembuhlah dia dari penyakitnya dan dia dapat berkumpul kembali bersama keluarganya. Maka mereka kemudian berkembang biak sampai jumlah mereka dua kali lipat dari jumlah sebelumnya. Pada suatu ketika, Ayyub a.s. teringat atas sumpahnya, bahwa dia akan memukul isterinya bilamana sakitnya sembuh disebabkan isterinya pernah lalai mengurusinya sewaktu dia masih sakit. Akan tetapi tumbuh dalam hatinya rasa ibah dan sayang kepada isterinya sehingga dia tidak dapat memenuhi sumpahnya. Oleh sebab itu turunlah perintah Allah seperti yang tercantum dalam Ayat 44 tersebut, agar dia dapat melaksanakan sumpahnya dengan tidak menyakiti isterinya yaitu memukulnya dengan seikat rumput.

${ }^{54}$ Muhammad Usman al-Khasit, Sulitnya Berumah Tangga. 81. 
sifatnya. Memukul hanya pada satu tempat, karena akan menambah rasa sakit dan akan memperbesar timbulnya bahaya. Dalam rangka memberi pendidikan bagi isteri yang nushuz ar-Razi dan at-Tabari juga memiliki pemahaman yang tidak jauh berbeda dengan ulama fiqh. Mereka tidak menafikan adanya kemungkinan untuk memukul isteri asal telah diyakini melakukan nushur: ${ }^{55}$ Hanya saja untuk masalah pemukulan ini, kedua mufassir tersebut sepakat memberikan catatan bahwa pukulan yang dibenarkan adalah pukulan yang tidak menyakitkan, yang tidak melukai, tidak mematahkan tulang dan tidak merusak muka. Selain itu ada yang membatasi hukuman fisik hanya dengan miswak atau sapu tangan memukul istri dengan sapu tangan atau miswak mungkin telah adil dan lembut dalam konteks di mana kekerasan terhadap perempuan sebelumnya telah diterima secara budaya. ${ }^{56}$

Muhammad Abduh berpendapat bahwa perintah memukul isteri bukanlah sesuatu yang bertentangan dengan akal dan fitrah. Memukul diperlukan jika keadaan sudah buruk dan akhlak isteri sudah rusak. Suami boleh memukul isteri ketika suami melihat bahwa rujuknya isteri hanya dengan cara memukulnya. Akan tetapi, jika keadaan sudah membaik dan isteri sudah tidak nushuz lagi cukup dengan cara menasehatinya atau mengasingkannya dari tempat tidur, maka tidak perlu memukulnya. Setiap keadaan menentukan hukuman yang sesuai, sementara itu kita diperintahkan menyayangi kaum perempuan, tidak menganiaya, menjaganya dengan cara yang baik, dan jika menceraikannya harus dengan cara yang baik pula.

Terdapat penjelasan yang menarik dari Rasyid Ridha, yaitu penolakannya terhadap anggapan orang bahwa Islam menindas kaum perempuan karena adanya perintah pemukulan ini. Ia menggariskan bahwa pemukulan dilakukan sebagai langkah terakhir jika langkah-langkah sebelumnya tidak berhasil, dan itupun harus dalam batas tidak menyakitkan. Lebih lanjut ia menyatakan: "jangan membayangkan kaum perempuan Islam itu lemah dan kurus yang dagingnya disobek-sobek oleh cemeti suaminya." Untuk itu, ia mengutip hadis Rasulullah SAW; "Apakah salah satu diantara kalian akan memukul isterinya seperti halnya memukul budak lalu menyetubuhinya di malam hari?". Menurut Rasyid Ridha pemukulan adalah obat pahit dan ia mengatakan bahwa laki-laki yang saleh tidak akan memukuli perempuan (isterinya) walaupun itu diperbolehkan.

Hak suami dalam memukul merupakan salah satu hak yang mengundang polemik dan perdebatan panjang, khususnya dikalangan ulama fiqh, ahli tafsir (mufassir) dan pemikir-pemikir feminis kontemporer. Para ulama sepakat dengan pemukulan terhadap isteri nushuz diperbolehkan apabila masih dalam batas-batas yang wajar dan tidak bertujuan untuk menyakiti, karena pada

${ }^{55}$ Wa ad-darbu mubah wa tarkubu afdal (pemukulan itu boleh dan meninggalkannya lebih baik) lihat Rasyid Ridha dan Muhammad Abduh, Tafsir al-Manar, 74.

${ }^{56}$ M. Hisham kabbani and Homayra Ziad, The Prohibition of Domestic Violence in Islam (Washington: Worde, 2011), 12 
dasarnya ulama lebih menekankan agar tidak memukul. Sedangkan para feminis berpendapat bahwa pemukulan tidak pernah dianjurkan oleh Al-Qur'an. ${ }^{57}$

Al-Qur'an justru ingin mencegah pemukulan terhadap istri dan secara bertahap menghapuskannya. Sabda-sabda Nabi SAW setelah itu menunjukkan pelarangan pemukulan terhadap istri. Umar memprotes Nabi SAW atas larangannya itu. Menurutnya, istri-istri kami akan bertindak semaunya bila mereka mendengar tentang ini. Tetapi pada saat yang lain, ketika banyak perempuan mengeluhkan pemukulan suami mereka, Nabi bersabda, “.... Mereka memukul istri mereka dan tidak bertingkah laku baik. Sungguh bukan termasuk pengikutku, mereka yang menyebabkan perempuan menjadi tidak baik."

Ayat - ayat al-Qur'an menjelaskan bahwa Allah menganjurkan sikap ma'ruf dalam perkawinan. Berdasarkan pemaparan diatas maka jelaslah bahwa hukum Islam adalah hukum yang tidak mendiskriminasikan perempuan khususnya dalam rumah tangga. Memukul hanya dapat dilakukan setelah nushur istri dilakukan berulang kali setelah melalui dua tahap sebelumnya. Selain itu jika dilihat dari konteksnya, pemukulan itu diperkenankan sehubungan dengan kegarangan perempuan terhadap suaminya. Jadi, bukan dalam kondisi yang biasa sehingga dengan alasan ayat tersebut, suami sewenang-wenang memukul istrinya.

Amina Wadud menjelaskan dalam bukunya yang berjudul Qur'an and Women, bahwa nushuzadalah gangguan keharmonisan keluarga, dengan mengutip surat an-nisa' Ayat 34. Amina berpendapat bahwa maksud ayat tersebut adalah untuk memberi jalan pemecahan ketidakharmonisan antara suami dan isteri. ${ }^{58}$ Oleh karena itu dalam memahaminya sebagai sebuah dalil yang membolehkan seorang suami memberikan hukuman atau sanksi kepada isteri yang nushuz. adalah tidak tepat.

Amina setuju dengan dua cara pertama dalam menyikapi isteri nushuz, yaitu manasehati dan menjauhinya dari tempat tidur. Mengenai cara yang ketiga yaitu memukul, dia menentangnya. Menurutnya memukul bukanlah jalan terbaik dan tidak akan dapat menyelesaikan masalah yang terjadi, justru akan semakin membuat persoalan menjadi berat. Memukul harus dimaknai sebagai cara untuk kembali mengadakan usaha damai dan kalau tidak bisa maka lebih baik diakhiri dengan perceraian.

Berdasarkan pemaparan tersebut dapat disimpulkan bahwa pemukulan yang dimaksud bukanlah pemukulan yang bersifat hakiki melainkan hanya untuk memenuhi tujuan secara psikologis. Pemukulan juga dapat dilakukan apabila permasalahan yang ada tidak dapat diselesaikan dengan dua tahap sebelumnya.

${ }^{57}$ Pendapat ini dilontarkan oleh para kaum feminis seperti Ashgar Ali Engineer, ia berpendepat dengan mengutip pendapat Ahmed Ali dari kitab Ragib Al-Mufradat fi Garib Al-Qur'an yang menerangkan bahwa kata dharaba mempunyai makna metaforis yaitu melakukan hubungan seksual lihat Asghar Ali Engineer, The Right of Women in Islam, 76.

58 Amina Wadud, Qur'an and women, 21. 


\section{Pembaharuan Hukum Formal Keluarga Islam di Indonesia}

Pembaharuan dalam bidang hukum selalu diperlukan karena masyarakat selalu berubah statis..$^{59}$ Menurut Satjipto Rahardjo perubahan yang terjadi dalam kehidupan masyarakat dapat digolongkan kedalam dua kategori, yaitu Pertama, Perubahan yang lambat, yang inkremental, bertambah sedikit demi sediki, dan kedua Perubahan dalam skala besar, perubahan revolusioner. ${ }^{60}$

Soetandyo Wignjosoebroto membedakan pembaruan hukum dalam arti legal reform dengan pembaruan hukum dalam arti law reform. Pembaruan hukum dalam arti legal reform diperuntukkan bagi masyarakat dimana hukum hanya sebagai subsistem dan berfungsi sebagai tool of social enginering sematamata. Hukum hanya menjadi bagian dari proses politik yang mungkin juga progresif dan reformatif. Pembaruan hukum di sini kemudian hanya berarti sebagai pembaharuan undang-undang sebagai proses politik.

Soetandyo juga menyatakan bahwa pembaharuan hukum hanya melibatkan pemikiran-pemikiran kaum politisi atau sedikit kaum elit profesional yang memiliki akses lobi. Pembaruan hukum dalam arti law reform bukan hanya merupakan urusan para hakim dan penegak hukum lainnya, tetapi juga merupakan urusan publik. Secara umum dalam konsep ini hukum adalah produk aktivitas politik rakyat yang berdaulat, yang digerakkan oleh kepentingan rakyat yang berdaulat serta diilhami oleh kebutuhan ekonomi, norma sosial, atau nilainilai ideal kultur rakyat itu sendiri. ${ }^{61}$

Abdul Manan menyatakan bahwa terdapat dua pandangan dominan berkaitan dengan perubahan (tentu dalam arti pembaruan) hukum yang berlaku dalam kehidupan masyarakat dalam suatu negara, yaitu pandangan tradisional dan pandangan modern. Pandangan tradisional menyatakan bahwa masyarakat harus berubah terlebih dahulu baru hukum datang mengaturnya, sebaliknya dalam pandangan modern, agar hukum dapat menampung segala perkembangan baru, hukum harus selalu berada bersamaan dengan peristiwa yang terjadi. Abdul Manan juga menjelaskan bahwa dalam bidang hukum yang netral perubahan harus ditujukan untuk melahirkan suatu kepastian hukum, sebaliknya dalam bidang kehidupan pribadi hukum harus berfungsi sebagai sarana sosial kontrol dalam kehidupan masyarakat. ${ }^{62}$

${ }^{59}$ Kamus Besar Bahasa Indonesia (KBBI) mengartikan kata “pembaruan” sebagai proses, cara, perbuatan membarui. Membarui itu sendiri menurut KBBI bermakna (1) memperbaiki supaya menjadi baru, (2) mengulangi sekali lagi, memulai lagi dan (3) mengganti dengan yang baru, memodernkan. Depdiknas, Kamus Besar Babasa Indonesia (Jakarta: Balai Pustaka, 2005), 109.

${ }^{60}$ Satjipto Rahardjo, Membangun dan Merombak Hukum Indonesia (Yogyakarta: Genta Publishing, 2009), 190.

${ }^{61}$ Soetandyo Wigjosoebroto, Pembaharuan Hukum Masyarakat Indonesia Baru (Jakarta: Ford Foundation \& HUMA, 2007), 94.

${ }^{62}$ Abdul Manan, Aspek-Apek Pengubah Hukum (Jakarta: Prenada Media, 2005), 7. 
Mochtar Kusumaatmadja membagi hukum menjadi dua yaitu bidang hukum netral dan non-netral, bidang hukum netral seperti hukum dalam bidang perekonomian dapat dilakukan pembaharuan dalam bentuk unifikasi, tetapi dalam bidang hukum non-netral seperti bidang hukum keluarga pembaharuan dalam bentuk unifikasi tidaklah mudah karena menyangkut kultur dan keyakinan masyarakat serta sulit diterapkan pada masyarakat yang prularis seperti Indonesia. ${ }^{63}$ Akan tetapi dalam hal ini Indonesia mempunyai pengalaman unik karena telah berhasil melakukan unifikasi bidang hukum non-netral, yaitu dengan lahirnya Undang-Undang Nomor 1 Tahun 1974 Tentang Perkawinan karena masih mentolerir adanya pluralisme hukum.

Unifikasi hukum dimulai setelah kemerdekaan Indonesia 1945, karena terdapat banyak hukum dan regulasi berbasis Islam yang dikeluarkan oleh negara. Salah satu perkembangan yang penting untuk dicatat adalah keluarnya peraturan tentang institusionalisasi lembaga peradilan agama dan peralihan kekuasaan peradilan agama dari Menteri Kehakiman kepada Menteri Agama di tahun 1950-an. ${ }^{64}$ Selama proses evolusi yang panjang dan dinamis kebutuhan atau tuntutan untuk dilakukannya reformasi hukum Islam telah disuarakan dalam tiga dekade terakhir. Hasil pertama dari proses reformasi di tahun 1974 yaitu ketika pemerintah Indonesia mengeluarkan UU No. 1 tentang Hukum Perkawinan yang secara substansial mengakomodasi ide para reformis.

Terjadinya Pembaharuan hukum ditandai oleh adanya berbagai instrumen hukum yang menjamin kesetaraan dan keadilan, bersumber dari berbagai konvensi international, hukum positive nasional, termasuk juga berbagai jurisprudensi atas kasus-kasus dimana perempuan mendapat keadilan. Dalam perundang-undangan di Indonesia sebenarnya jaminan keadilan baik bagi perempuan maupun laki-laki dapat dilihat dari berbagai peraturan perundangundangan seperti dalam undang-undang dasar 1945 pasal 27 ayat 2. UndangUndang Penghapusan Kekerasan dalam Rumah Tangga, UU no. 7/1984 sebagi ratifikasi terhadap konversi CEDAW yang sangat komprehensif menganut larangan diskriminasi terhadap perempuan hampir di segala bidang kehidupan. Namun terdapat perbedaan antara teori dalam perundang-undangan (das sollen ) dan implementasi dalam kehidupan sehari-hari (das sein) sehingga hukum hanya dapat dipandang sebagai payung fantasi. ${ }^{65}$

Pada tahun 1974 pemerintah Indonesia melakukan unifikasi dalam bidang hukum perkawinan yaitu Undang-Undang No. 1 Tahun 1974, namun demikian undang-undang ini memperlihatkan sikap pemerintah yang ambivalen/ambigu, di satu pihak mengakui legal capacity kaum perempuan (istri). Namun dipihak

${ }^{63}$ Mochtar Kusumaatmadja, Konsep-konsep Hukum dalam Pembangunan (Bandung: Pusat Studi Wawasan Nusantara, Hukum dan Pembangunan Alumni, 2002), 24.

${ }^{64}$ Daniel S. Lev, Islamic Courts in Indonesia: A Study in the Political Base of Legal Institutionsm (Berkeley: University of California Press, 1972), 64-100.

${ }^{65}$ Gandi, Hukum Islam di Indonesia (Jakarta: Gramedia, 1995), 36. 
lain justru mengukuhkan peranan berdasarkan jenis kelamin (sex roles) dan pelebelan (Stereotype) terhadap perempuan serta laki-laki dengan membagi secara kaku peran perempuan disektor domestik dan peran laki-laki disektor publik.

Ambivalensi pemerintah dalam kebijakan hukum, kelembagaan dan ideologi memberi sumbangan besar terhadap terjadinya kesenjangan antara niat untuk menghapuskan diskriminasi dan meningkatkan status perempuan dengan praktik hukum dan kebijakan yang dijalankan, sebagai contoh budaya patriarki yang dianut oleh Indonesia dan negara timur tengah seperti Arab menimbulkan Pola relasi suami istri yang tidak setara. ${ }^{66}$ Berdasarkan hal tersebut Undang-Undang No. 1 Tahun 1974 belum dapat dikatakan berhasil sepenuhnya. Karena, materi dalam hukum perkawinan sendiri masih bersifat plural, sedangkan yang berhasil diunifikasikan hanya segi administratifnya saja. ${ }^{67}$

Konfigurasi hukum Islam pada masa orde baru mempunyai karakterkarakter yang spesifik, berbeda dengan karakter produk hukum pada umumnya, dan juga berlainan dengan karakter dasar hukum Islam yang ideal. Munculnya spesifikasi karakter merupakan implikasi dari konfigurasi politik hukum orde baru, sebuah bingkai politik di mana hukum Islam dilegislasikan. Dengan kata lain, konfigurasi politik hukum Islam merupakan hasil perbenturan antara kepentingan hukum agama (Islam) dengan kehendak-kehendak sosial politik hukum negara. Masing-masing mempunyai dan berdiri diatas paradigmanya sendiri. Kompilasi Hukum Islam (KHI) yang saat ini dianggap sebagai bentuk maksimal dan akumulasi dari aturan-aturan hukum Islam dalam tata hukum Indonesia adalah wujud dari perbenturan dan perjuangan politik tersebut. ${ }^{68}$ Apabila digambarkan pembaharuan hukum keluarga Islam dalam sejarah Indonesia adalah sebagai berikut:

${ }^{66}$ Elizabeth Warnock Fernea, Women and The Family In The Middle East (Austin: University of Texas Press, 1995), 37.

${ }^{67}$ Ahmad Tholabi Kharlie, Kesadaran Hukum Masyarakat terhadap Hukum Perkawinan (Jakarta: Lembaga Penelitian UIN, 2009), 143.

${ }^{68}$ Rumadi, "Independensi Agama Vis a Vis Negara Refleksi atas Politik Hukum Islam di Indonesia" dalam Masykuri Abdillah, Formalisasi Syariat Islam di Indonesia Sebuah Pergulatan yang Tak Pernah Tuntas (Jakarta: Renaisan, 2005), 99. 
Tabel 3.1.

\begin{tabular}{|l|l|l|l|l|}
\hline Periode & Tahun & Produk Hukum & Ditujukan & Keberhasilan \\
\hline Merdeka & 1945 & $\begin{array}{l}\text { Stbld 198/1895 } \\
\text { NTCR }\end{array}$ & WNI & Disahkan \\
\hline Merdeka & 1950 & $\begin{array}{l}\text { RUU } \\
\text { Perkawinan }\end{array}$ & - & Gagal \\
\hline Orde Baru & 1966 & - & - & - \\
\hline Orde Baru & 1974 & $\begin{array}{l}\text { Undang- } \\
\text { Undang } \\
\text { Perkawinan }\end{array}$ & WNI & Disahkan \\
\hline Orde Baru & 1991 & KHI & WNI Muslim & Disahkan \\
\hline Reformasi & 2003 & RUUHTPA & WNI & Gagal \\
\hline Reformasi & 2004 & CLD-KHI & WNI Muslim & Gagal \\
\hline
\end{tabular}

Eksistensi hukum Islam di Indonesia selalu mengambil dua bentuk; hukum normatif yang diimplementasikan secara sadar oleh umat Islam dengan menggunakan pendekatan kultural dan hukum formal yang dilegislasikan sebagai hukum positif bagi umat Islam. Kedua bentuk hukum tersebut menggunakan penghampiran structural yang dalam proses legislasinya dengan dua cara.

Pertama, hukum Islam dilegislasikan secara formal untuk umat Islam, seperti PP Nomor 28 Tahun 1977 tentang Perwakafan, UU Nomor 17 Tahun 1999 tentang Penyelenggaraan Ibadah Haji, dan UU Nomor 38 Tahun 1999 tentang Pengelolaan Zakat. Kedua, materi-materi hukum Islam diintegrasikan ke dalam hukum nasional tanpa menyebutkan hukum Islam secara formal, seperti UU Nomor 1 Tahun 1974 tentang Perkawinan dan UU Nomor 7 tahun 1989 tentang Peradilan Agama. ${ }^{69}$ Berbeda dengan itu, KHI dalam sejarahnya adalah produk kebiakan hukum pemerintah yang proses penyusunannya didasarkan pada hukum normatif Islam, terutama fikih madzhab Shaf'i sehingga membuat KHI tidak akrab dengan hukum-hukum nasional dan internasional yang memiliki komitmen kuat pada tegaknya masyarakat yang egaliter, pluralis, dan demokratis. Menurut beberapa kalangan karena keinginan KHI sendiri beberapa pasalnya mengandung potensi sebagai penghambat laju gerak demokrasi di Indonesia. Kalau pasal-pasal tersebut tetap dibiarkan, maka KHI akan terus menerus turut menyuburkan praktik diskriminasi dalam masyarakat, terutama terhadap perempuan dan kaum minoritas.

${ }^{69}$ Agysa, Himpunan Undang-Undang Peradilan (Jakarta: Asa Mandiri, 2010), 49. 
Praktik tersebut tentu saja bertentangan dengan produk-produk hukum nasional, seperti UU Nomor 7 Tahun 1984 tentang Penghapusan Segala Bentuk Diskriminasi terhadap Perempuan. Undang-Undang yang terakhir ini dirumuskan sebagai konsekuensi logis dari ratifkasi negara terhadap CEDAW (The Convention on the Elimination of All Form of Discrimination Against Women), UU Nomor 39 Tahun 1999 tentang HAM yang isinya sangat menekankan upaya perlindungan dan penguatan terhadap perempuan, bahkan dengan UUD 1945 dan Amandemen UUD 1945. Dalam hal-hal tertentu, praktik diskriminasi juga berseberangan dengan UU Nomor 22 Tahun 1999 tentang Pemerintahan Daerah yang menekankan pada prinsip desentralisasi dengan ciri partisipasi seluruh masyarakat tanpa membedakan laki dan perempuan. $^{70}$

Pada tataran internasional, terdapat sejumlah instrumen penegakan dan perlindungan HAM, antara lain Deklarasi Universal HAM (1948), Kovenan Internasional tentang Hak-hak Sipil dan Politik (1966), Kovenan Internasional tentang Hak-hak Ekonomi, Sosial, dan Budaya (1966), CEDAW (1979), Deklarasi Kairo (1990), dan Deklarasi dan Program Aksi Wina (1993). Sebagai dampak dari kesepakatan-kesepakatan tersebut, Kompilasi Hukum Islam kiranya tidak bisa mengelak kecuali harus menyesuaikan diri dengan ketentuanketentuan tersebut.

Apabila dilihat dari proses pembentukannya KHI lahir bukan dari kondisi yang vakum. Ada kondisi-kondisi sosial, politik, dan hukum yang mendorong terbentuknya KHI. KHI lahir sebagai produk politik negara Orde Baru, yang jika dipandang dari optik politik hukum tentu saja tidak bebas nilai dan tidak bebas kuasa dari muatan interest politik rezim itu. Dengan kata lain, pembidanan kelahiran dan keberadaan KHI terselimuti oleh bias-bias kekuasaan rezim orde baru. Setiap legislasi yang dikeluarkan oleh negara terutama pada masa orde baru yang pada saat itu berwatak otoritarian-birokratik, terdapat suatu kehendakkehendak sosial politik tersembunyi yang menyertainya, sebagaimana yang dianut oleh banyak pakar hukum bahwa tak ada hukum yang bebas nilai, bebas kepentingan, dan bebas kuasa.

Salah satu contohnya adalah hukum Islam yang terkumpulkan dalam KHI, kehadirannya menjadi sarat dengan nilai, kepentingan, dan relasi kuasa. Kebijakankebijakan hukum untuk perempuan yang dikeluarkan sejak masa orde baru, tidak lepas dari berbagai kepentingan politik dan ekonomi pemerintah untuk membangun kembali perekonomian negara. Paradigma yang digunakan adalah modernisasi dengan pertumbuhan ekonomi dan stabilitas politik. Oleh karena itu seluruh anggota masyarakat termasuk kaum perempuan dimobilisasikan untuk kepentingan tersebut dengan kontrol yang ketat dari negara. Kontrol tersebut dilakukan melalui berbagai kebijakan dan hukum, kelembagaan dan

${ }^{70}$ Pokja Pengerusutamaan Jender, Menuju Kompilasi Hukum Islam (KHI) yang Adil Gender dalam modul Dawrah Fiqh Perempuan (Jakarta: Departemen Agama), 283. 
ideologi yang ditujukan untuk mengejar pertumbuhan ekonomi dan stabilitas politik. ${ }^{71}$ Dalam konteks masyarakat patriarki, kebijakan tersebut sangat berpengaruh terhadap kehidupan perempuan. Kebijakan dan hukum yang dikeluarkan merupakan produk politik yang sarat dengan berbagai kepentingan serta berakibat pada kebijakan hukum yang tidak netral. Tidak hanya kepentingan politik dan ekonomi yang melatarbelakangi kelahiran kebijakan hukum, tetapi juga melalui nilai-nilai dominan yang dianut masyarakat, apabila nilai-nilai dominan yang terdapat dalam masyarakat adalah patriarki atau ideologi jender, maka kebijakan dan hukum yang dihasilkan mengukuhkan atau mengandung bias-bias patriarki dan ideologi jender, kondisi tersebut akan berpengaruh pada implementasi dan budaya hukum masyarakatnya. Faktor lain yang melatarbelakangi kebijakan negara untuk perempuan juga dipengaruhi oleh sistem hukum kolonial yang menerapkan pluralisme hukum (plural legality) dan ketidaksamaan rasial (racial inequality).

Berdasarkan hal tersebut sangatlah wajar apabila KHI dipandang oleh sebagian orang sebagai "fikih madzhab negara" karena elemen-elemen konstruksi hukum Islam dalam KHI mulai dari inisiatif, proses penelitian, penyusunan, hingga penyimpulan terakhir dari pilihan-pilihan hukumnya dilakukan oleh suatu tim yang beranggotakan hampir seluruhnya orang-orang negara. Betapa latar belakang pembentukan, logika hukum yang digunakan, hingga pola redaksi yang diterapkan juga sebagaimana lazimnya digunakan oleh hukum positif negara. Bahkan, legitimasi hukum pemberlakuannya juga sangat bergantung pada keputusan negara melalui Instruksi Presiden. Apabila dilihat dari kajian politik hukum, KHI setidak-tidaknya memiliki 4 (empat) buah karakter hukum yang spesifk sebagai akibat logis dari pengaruh politik hukum pada masanya. Karakter-karakter tersebut adalah sebagai berikut; pertama, jika dilihat dari perspektif strategi pembentukan hukum, KHI berkarakter semi-responsif, yakni proses pembentukannya dikuasai oleh pihak yudikatif (MA) dan eksekutif (Depag RI), sementara pihak legislative (DPR) selaku perwakilan-formal rakyat. ${ }^{72}$

Indonesia tidak terlibat sama sekali dan perwakilan masyarakat Islam (MUI dan cendekiawan Muslim di IAIN) berada pada posisi peripheral; kedua, jika dilihat dari perspektif materi hukum, KHI berkarakter otonom, reduksionistik dan konservatif, artinya materi hukum Islam pada KHI secara substansial diakui sebagai fiqh (yurisprudensi Islam), namun hanya sebagian kecil materi hukum Islam yang dilegislasikan [perkawinan, kewarisan, dan perwakafan] dengan formulasi bahasa dan pokok masalah yang tidak adaptif dan inovatif; ketiga, jika dilihat dari perspektif implementasi hukum, KHI berkarakter fakultatif, yakni tidak secara a priori harus ditaati dan bisa memaksa setiap warga negara,

${ }^{71}$ Nursyahbani Katjasungkana, Perempuan dalam Peta Hukum Negara di Indonesia, 69.

72 Pokja Pengerusutamaan Jender, Menuju Kompilasi Hukum Islam (KHI) yang Adil Gender dalam Modul Dawrah Fiqh Perempuan, 284. 
meski beragama Islam, untuk melaksanakan ketentuan KHI; dan yang keempat jika dilihat dari perspektif fungsi hukum, KHI berkarakter regulatif dan legitimatif, yakni ketentuan hukumnya lebih bersifat teknis-prosedural dan praktis-operasional ketimbang strategis-konsepsional dan teoritik. ${ }^{73}$

Aturan-aturan hukum dalam KHI juga cenderung melakukan pembenaran terhadap ketentuan hukum positif sebelumnya dan institusi-institusi bentukan negara, seperti KUA, PPAIW, Pengadilan Agama, dan lain-lain. Sehingga, hukum Islam dalam KHI telah bergeser dari otoritas hukum agama [divine law] menjadi otoritas hukum negara [state law]. Penyusunan KHI berlangsung selama tahun antara 1985-1991 dan pada tanggal 10 Juni 1991 berdasarkan instruksi presiden (Inpres) 1991, KHI dikukuhkan sebagai pedoman resmi dalam bidang hukum material bagi para hakim di lingkungan pengadilan agama seluruh Indonesia. Akan tetapi menurut beberapa kalangan KHI perlu dikaji secara serius dengan pendekatan yang komprehensif setidaknya melalui pengkajian ulang dalam empat pendekatan utama yaitu jender, pluralisme, hak asasi manusia dan demokrasi. $^{74}$

Pembaharuan hukum Islam juga disebabkan oleh beberapa faktor antara lain: pertama, untuk mengisi kekosongan hukum karena norma-norma yang terdapat dalam kitab-kitab fikih tidak mengaturnya, sedangkan kebutuhan hukum masyarakat terus berkembang; kedua, pengaruh globalisasi ekonomi dan Iptek; ketiga, pengaruh reformasi di berbagai bidang yang memberikan peluang kepada hukum Islam untuk menjadi acuan dalam hukum nasional; dan keempat, pengaruh pembaruan pemikiran hukum Islam, baik oleh pakar hukum Islam manca negara maupun pakar hukum Islam nasional, terutama menyangkut perkembangan ilmu pengetahuan dan teknologi serta isu-isu jender. ${ }^{75}$ Khusus tentang pembaruan hukum keluarga, termasuk di dalamnya adalah faktor unifikasi dan kodifikasi hukum keluarga Islam Indonesia. ${ }^{76}$ Berikut ini akan penulis paparkan beberapa hal terkait pebaharuan hukum formal keluarga Islam di Indonesia.

Pembaharuan hukum yang terjadi adalah putusnya perkawinan di Indonesia dalam hal tersebut berawal dari Undang- undang no. 1 tahun 1974 yang menyatakan putusnya perkawinan harus didepan pengadilan dan tidak ada perbedaan antara perceraian yang diajukan oleh istri maupun oleh suami akan tetapi terjadi pembaharuan hukum terhadap hal tersebut jika dilihat dalam KHI terjadi perbedaan antara gugatan cerai yang diajukan oleh istri disebut cerai

${ }^{73}$ Pokja Pengerusutamaan Jender, Menuju Kompilasi Hukum Islam (KHI) yang Adil Gender, 285.

${ }^{74}$ Kalangan yang dimaksud adalah Tim Pengarusutamaan Jender Depag RI yang mendapat dukungan dana dari Asia Foundation.

75 Abdul Manan, Reformasi Hukum Islam di Indonesia (Jakarta: Raja Grafindo, 2006), 154.

${ }^{76}$ Abu Bakar Zainal Abidin, Kumpulan Peraturan Perundang-undangan dalam Lingkungan Peradilan Agama (Jakarta: Al-Hikmah, 1993), 53. 
gugat dan yang diajukan oleh suami disebut cerai talak. Selain cerai gugat KHI juga menjelaskan ketentuan tentang khulu'. Putusnya perkawinan karena perceraian harus dilakukan di depan pengadilan, hal tersebut merupakan upaya terakhir untuk mencapai adanya kepastian hukum mengenai status seseorang dalam perkawinan. Perceraian dapat dilakukan oleh istri maupun suami. Dalam fiqh perceraian yang diajukan oleh pihak istri disebut kbulu'.

Khulu' dipihak istri dianggap sebagai pertukaran hak tuntutan, sedangkan dipihak suami dianggap sebagai persetujuan dibawah sumpah sehingga dia tidak dapat menarik khulu' yang telah dilakukan oleh istri. ${ }^{77}$ Imam malik mendefinisikan kbulu' sebagai kbulu' 'al-talaq bi al 'iwad yaitu perceraian dengan memberikan ganti rugi, Imam hanafi mengatakan bahwa khuluk merupakan pengakhiran sebuah pernikahan dengan persetujuan sedangkan imam shafi'i mengatakan bahwa khuluk merupakan perceraian yang terjadi karena pengembalian sesuatu yang dibarengi dengan ucapan cerai atau khuluk. Abdurrahman I doi menyatakan bahwa khuluk berdasarkan kesepakatan kedua belah pihak di depan pengadilan dengan pembayaran kepada pihak istri kepada suaminya sejumlah barang tertentu yang tidak lebih dari mahar yang telah diberikan kepadanya saat pernikahan. ${ }^{78}$

Khulu' hanya dibolehkan dengan adanya alasan yang benar. Jika tidak ada alasan yang benar maka hukumnya makruh. Dalam satu hadits dari Abi Hurairah yang diriwayatkan oleh Ahmad dan Nasa'i, diterangkan bahwa seorang isteri yang meminta kbulu' tanpa alasan yang benar adalah perempuan munafik. Secara implisit dapat dipahami bahwa hal pokok yang menjadi alasan khuluk bagi istri berdasarkan nash syar'i karena kekhawatiran tidak akan dapat menjalankan hukum-hukum Allah. Hal ini bisa disebabkan istri tidak mencintai suami, suami tidak menjalankan perintah agama, suami mengajak kepada kemaksiatan, kesyirikan, bahkan kemurtadan atau suami sangat buruk akhlaknya sehingga istri bisa terpengaruh. Dari sini bisa dipahami bahwa perceraian melalui jalan khulu' berorientasi kepada nilai-nilai keimanan dan ketauhidan kepada Allah SWT.

Secara yuridis perceraian melalui jalan kbulu' hanya diatur dalam Kompilasi Hukum Islam, ditambah dengan praktik yang berlaku di Pengadilan Agama. Sebelum diberlakukannya Kompilasi Hukum Islam di Indonesia dengan Instruksi Presiden Nomor 1 Tahun 1991 pada tanggal 10 Juni 1991 yang dilaksanakan dengan Keputusan Menteri Agama Republik Indonesia Nomor 154 Tahun 1991 pada tanggal 22 Juli 1991. Pengadilan Agama hanya mengenal adanya dua jenis perkara perceraian, yaitu perkara permohonan cerai talak dari suami dan perkara cerai gugat dari pihak isteri. Dalam Kompilasi Hukum Islam terdapat istilah yang berbeda menyangkut prosedur perceraian antara suami dan istri.

${ }_{77}$ Joseph Schacht, An Introduction to Islamic law (Oxford: Clarendon Press,1997), 211.

${ }^{78}$ Abdurrahman I doi, Shariah: The Islamic Law (Kuala Lumpur: As. Noordeen, 1989), 192. 
Untuk laki-laki digunakan istilah permohonan bercerai, sementara untuk perempuan digunakan istilah gugatan bercerai. ${ }^{79}$ Dengan diberlakukannya Kompilasi Hukum Islam ada perubahan signifikan dalam perkara perceraian di Pengadilan Agama, yaitu berlakunya Hukum Acara Khulu’. Namun berlakunya acara perceraian dengan cara khuluk' (talak tebus) tidak melahirkan jenis perkara perceraian yang baru di Pengadilan Agama. Acara khulu' menjadi bagian dari perkara cerai gugat dengan tambahan putusan mengenai tebusan yang harus dibayar oleh isteri dan perceraian terjadi dengan jatuhnya talak khuluk dari suami. $^{80}$

Berdasarkan pemaparan di atas dapat disimpulkan bahwa telah terjadi pembaharuan hukum formal keluarga di Indonesia, pembaharuan hukum formal yang pertama adalah dengan di sahkannya Undang-Undang No. 1 Tahun 1974. Pembaharuan selanjutnya dengan dikeluarkannya Kompilasi Hukum Islam yang dikeluarkan dalam bentuk Inpres materi muatan hukum yang terdapat dalam kedua produk hukum tersebut juga telah mengalami progress yang cukup signifikan.

\section{Penutup}

Beberapa fakta menunjukkan bahwasannya peraturan terkait sanksi dipandang dalam perspektif jender belum memberikan keadilan, sanksi yang dimaksud adalah sanksi terhadap perempuan yang terdapat dalam hukum keluarga diantaranya sanksi ketika istri nushuz dan cerai gugat. Peraturan terkait sanksi masih mengakomodir ketentuan dalam figh. Adapun peraturan yang dimaksud terkait sanksi tersebut adalah hukum formil keluarga Islam khusunya di Indonesia. Hukum keluarga formil yang dimaksud disini adalah KHI.

KHI adalah kumpulan hukum Islam produk pemerintah Indonesia masa Orde Baru yang isinya diambil dari sejumlah kitab fikih yang umumnya ditulis pada abad pertengahan. KHI disusun berdasarkan keputusan bersama ketua Mahkamah Agung dan Menteri Agama pada tanggal 21 Maret 1985 dan selanjutnya melahirkan proyek pengembangan hukum Islam melalui yurisprudensi selanjutnya KHI dikukuhkan sebagai pedoman resmi dalam bidang hukum material bagi hakim di lingkungan Peradilan Agama di seluruh Indonesia berdasarkan Inpres No. 1 Tahun 1991.

KHI merupakan respon pemerintah terhadap timbulnya berbagai keresahan di masyarakat akibat beragamnya keputusan Pengadilan Agama dalam kasus yang sama. Keberagaman tersebut hakikatnya merupakan konsekuensi logis dari beragamnya pandangan fiqh yang menjadi referensi para hakim agama

\footnotetext{
${ }^{79}$ Siti Musdah Mulia, "Kompilasi Hukum Islam Sangat Konservatif" dalam Ijtihad Islam Liberal Upaya merumuskan Keberagamaan yang Dinamis (Jakarta: Jaringan Islam Liberal, 2005), 171.

${ }^{80}$ ArisBintania,"Hukum Islam Vol VIII No 6",http://www.pdfbe.com/1e/ 1e70d11413f93e3b- download.pdf (diakses pada 25 Maret 2012).
} 
dalam merumuskan suatu perkara. Jika dilihat dari perspektif kesetaraan dan keadilan jender, sejumlah pasal dalam KHI yang memarjinalkan perempuan. KHI mengukuhkan pandangan dominan dalam figh yang menempatkan perempuan sebagai urutan kedua setelah laki-laki seperti dalam hal nushuz dan khulu'.

\section{Daftar Pustaka}

Coulson, Noel J. A History of Islamic Law. Edinburgh: University Press, 2004. Yanggo, Huzaemah Tahido. Fikih Perempuan Kontemporer. Jakarta: Ghalia Indonesia, 2010.

Ash Shaikh, Abdullah bin Wakil. Al-Mar'ah wa qa'id al-'Adl. Beirut: Ma'had al'Ulum al-Islamiyah wal al-'Arabiyah, 1993.

Ali,Yousuf. "A. Contextual Approach to the Views of Muslim Feminist Interpretation of the Qur'an Regarding Women and Their Rights," International Journal of Arts and Sciences 3 (2010), 320-321, http://www.openaccesslibrary.org/ images/HAR138_Md._Yousuf_Ali.pdf (diakses tanggal 22 Maret 2012.

Umar, Nasarudin, Argumen Kesetaraan Jender: Perspektif Al-Qur'an. Jakarta: Paramadina, 1999.

Qut\}hb, Sayid. Fi Zilal al-Qur'an. Kairo: Dar al-Shuruq, 1980.

Wadud, Amina. Quran and Women: Rereading the Sacred Text from a Woman's Perspective. Oxford: University Press, 1999.

Abu Abdillah, Muhammad Ahmad bin Abi Bakar bin Farh al-Qurtubi. AlJami' li Abkam al-Qur'an. Kairo: Dar al-Sha'ab, $1373 \mathrm{H}$.

Jamal, Ahmad Muhammad. Al-Nisa' wa al-Qadaya. Kairo: Maktab Ibnu Sina,1995.

Fakih, Mansour. Menggeser Konsepsi Gender dan Transformasi Sosial. Yogyakarta: Pustaka Pelajar, 1999.

Showalter, Elaine. Speaking of Gender. New York: Routledge, 1989.

Folley, Rebecca. "Muslim Women's Challenges to Islamic Law The Case of Malaysia," International Feminist Journal of Politics, 6 (2004), 53-84, http:/ /ipac.kacst.edu.sa/eDoc/2006/159807_1.pdf (diakses pada tanggal 25 Maret 2012).

Subhan, Zaitunah. Rekonstruksi Pemahaman Jender dalam Islam, Agenda Sosio-Kultural dan Politik Peran Perempuan. Ciputat: el-Kahfi, 2002.

Persons, Talcott and Robert F. Bales, Family Socialization and Interaction Process. Routladge: Kagan Paul, 2000.

M. Lips, Hilary. Sex and Gender: An Introduction. London: Mayfield Publishing Company, 1993.

Tavris, Carol. Mismaesure of Women. New York: Touchstone, 1992.

Ferre, Myra Marx and Judith Lorber. Revisioning Gender. Oxford: Altamira Press, 2000.

Ansori, Dadang S. Membincangkan Feminisme: Refleksi Muslimah atas Peran Sosial Kaum Wanita. Jakarta: Pustaka Hidayah, 1997. 
Neufieldt, Victoria. Webster's New World College Dictionary. New York: Mc Millan General Reference, 1996.

Ahmed, Leila. Wanita dan Gender dalam Islam: Akar-Akar Historis Perdebatan Modern. Jakarta: PT. Lentera Basitama, 2000.

Agustino, Leo. Perihal Ilmu Politik: Sebuah Bahasan Memahami Ilmu Politik. Yogyakarta: Graha Ilmu, 2007.

Hidayat, Rahmad. Ilmu Yang Seksi, Feminisme dan Perlawanan Terbadap Teori Sosial Maskulin. Yogyakarta: Jendela, 2004.

Mill, John Stuart. The Subjection of Women. Logman: Savili Edward,1955.

Umar, Nasaruddin. Argumen Kesetaraan Jender Perspektif Al-Quran. Jakarta: Paramadina, 2001.

Ramazanoglu, Caroline. Feminism and Contradiction. London: Routledge, 1989. Hidayat, Rahmad. Ilmu Yang Seksi Feminisme dan Perlawanan Terhadap Teori Sosial Maskulin. Yogyakarta: Jendela, 2004.

Al-Hakim, Al-Husain. Islam and Feminism, trans. Jemal Gembala. Jakarta : AlHuda, 2005.

Moghisi, Haideh. Feminisme dan Fundamentalisme Islam. Yogyakarta: LKiS, 2005. Saidah, Najmah dan Husnul Khatimah, Revisi Politik Perempuan Bercermin Pada Shahabiyat. Bogor : Pustaka Utama, 2003.

Yamani, Mai. Feminism and Islam : Legal and Literary Perspectives, trans. Purwanto. Bandung: Nuansa Cendikia, 2000.

Esposito, John L. Women in Muslim Family Law. New York: Cyracuse University Press, 1982.

Amin, Qasim. Sejarah Penindasan Perempuan Menggugat Islam laki-laki Menggugat Perempuan Baru, terj. Ircisod. Yogyakarta: Pustaka Setia, 2003.

Mahmood, Tahir. Family Law Reform In The Muslim World. New Delhi: The Indian Law Institute, 1972.

Hakeem, Ali Hossein, et. al. Membela Perempuan; Menakar Feminisme dengan nalar Agama. Jakarta: Al-Huda, 2005.

Murata, Sachito. The Tao of Islam. Bandung: Mizan, 1996.

Mernissi, Fatimah. Women's Rebellion and Islamic Memory. New York: Zed Books, 1996.

Al-Qadrani, Syauqi. Nushur. Jakarta: Gema Insani Press, 2004.

al-Khasit, Muhammad Usman. Sulitnya Berumah Tangga: Upaya Mengatasinya Menurut al-Qur'an dan Hadis, ilmu Pengetahuan. Jakarta: GIP, 1994.

Razi Al-Jassas, Abi Bakr Ahmad ibn 'Ali. Ahkam Al-Qur'an. Bairut: Dar alKutub al-Alamiyah, 1415 H/1993 M.

al-Ghazali, Abu Hamid Muhammad bin Muhammad. Ihya' 'Ulum ad-Din. Beirut: Dar al-Fikr, 1975.

al-Amili, Ali Husain Muhammad Makki. At-Talaq khoti'atu man?. Beirut: Mu'assasah Al-urwah al-wutsqa, t.th.

Sabiq, Said. Fiqh Al-Sunnah. Libanon: Dar al-Fikr, 1981.

Taqiyuddin. Kifayat al-Akbyar. Kairo: Isa al-babi al-halabi. 
Al-San'ani, Muhammad bin Ismail bin Salah. Subul al-Salam Sharb Buluq alMaram. T.tp, Cetakan Jamiah al-Imam Muhammad Ibnu Sa'ud alIslamiyah, $1408 \mathrm{H}$.

Murdani, Fithriyah Wardie. "Kewajiban dan Hak Suami Isteri dalam Keluarga Islam” dalam Al-Insan, No. 3, Vol. 2, Tahun 2006. Jakarta: Lembaga Kajian dan Pengembangan Al-Insan, 2006.

Shaikh, Sa'diyah. 'Exegetical Violence: Nushuz in Qur'anic Gender Ideology,' Journal for Islamic Studies 17 (1997), 49-73, http:/ /www.sistersinislam.org.my/ files/ downloads/saadiya/pdf (diakses pada tanggal 23 Maret 2011).

Kabbani, M. Hisham and Homayra Ziad. The Prohibition of Domestic Violence in Islam. Washington: Worde, 2011.

Rahardjo, Satjipto. Membangun dan Merombak Hukum Indonesia. Yogyakarta: Genta Publishing, 2009.

Wigjosoebroto, Soetandyo. Pembaharuan Hukum Masyarakat Indonesia Baru. Jakarta: Ford Foundation \& HUMA, 2007.

Manan, Abdul. Aspek-Apek Pengubah Hukum. Jakarta: Prenada Media, 2005. Kusumaatmadja, Mochtar. Konsep-konsep Hukum dalam Pembangunan. Bandung: Pusat Studi Wawasan Nusantara, Hukum dan Pembangunan Alumni, 2002.

Lev, Daniel S. Islamic Courts in Indonesia: A Study in the Political Base of Legal Institutionsm. Berkeley: University of California Press, 1972.

Gandi. Hukum Islam di Indonesia. Jakarta: Gramedia, 1995.

Fernea, Elizabeth Warnock. Women and The Family In The Middle East. Austin: University of Texas Press, 1995.

Tholabi Kharlie, Ahmad. Kesadaran Hukum Masyarakat terhadap Hukum Perkawinan. Jakarta: Lembaga Penelitian UIN, 2009.

Rumadi. "Independensi Agama Vis a Vis Negara Refleksi atas Politik Hukum Islam di Indonesia" dalam Masykuri Abdillah, Formalisasi Syariat Islam di IndonesiaSebuah Pergulatan yang Tak Pernah Tuntas. Jakarta: Renaisan, 2005.

Agysa. Himpunan Undang-Undang Peradilan. Jakarta: Asa Mandiri, 2010.

Pokja Pengerusutamaan Jender. Menuju Kompilasi Hukum Islam (KHI) yang Adil Gender dalam modul Dawrah Fiqh Perempuan. Jakarta: Departemen Agama.

Manan, Abdul. Reformasi Hukum Islam di Indonesia. Jakarta: Raja Grafindo, 2006. Abidin, Abu Bakar Zainal. Kumpulan Peraturan Perundang-undangan dalam Lingkungan Peradilan Agama. Jakarta: Al-Hikmah, 1993.

Schacht, Joseph. An Introduction to Islamic law. Oxford: Clarendon Press,1997.

Doi, Abdurrahman I. Shari'ah: The Islamic Law. Kuala Lumpur: As. Noordeen, 1989.

Mulia, Siti Musdah. "Kompilasi Hukum Islam Sangat Konservatif" dalam Ijtihad Islam Liberal Upaya merumuskan Keberagamaan yang Dinamis. Jakarta: Jaringan Islam Liberal, 2005.

Bintania, Aris. "Hukum Islam Vol VIII No 6",http://www.pdfbe.com/1e/ 1e70d11413f93e3b- download.pdf (diakses pada 25 Maret 2012). 